\title{
New species of Neogene radiolarians from the Southern Ocean - part III
}

\author{
JOHAN RENAUDIE* \& DAVID B. LAZARUS \\ Museum für Naturkunde, Leibniz-Institut für Evolutions- und Biodiversitätsforschung an der Humboldt-Universität zu Berlin, Invalidenstraße 43 , 10115 \\ Berlin, Germany \\ *Corresponding author (email: johan.renaudie@mfn-berlin.de)
}

\begin{abstract}
In this paper, the third of a series of four, 25 new species are described from the Neogene sediments of the Southern Ocean: six spumellarians (Actinomma telarania, Hexacontium? cooki, Lonchosphaera shackletoni, Joergensenium pseudodictyocha, Cryptolarnacium pauliani and Spongoplegma dentifrangibula) and nineteen nassellarians (Arachnocorallium cerebellum, A. stilla, A.? pyroensis, Amphiplecta? satoshii, Antarctissa kjelli, Lithomelissa celsagula, Botryopera piperata, B. vavato, Lophophaena? neuma, L.? globeacuculla, L. pileata, L. amictoria, Pseudodictyophimus ignatius, Spongomelissa? bipatens, Ceratocyrtis? arthuri, C.? ringisstola, Phormostichoartus ashbyi, Ceratospyris clinamen and Dorcadospyris kennetti).
\end{abstract}

KEYWORDS: Radiolaria, Polycystinea, Antarctic, Cenozoic, taxonomy

\section{INTRODUCTION}

Although Antarctic Neogene radiolarians have been studied since the beginning of the twentieth century (e.g. Popofsky, 1908), the fauna is yet to be documented exhaustively at the species level. With Renaudie \& Lazarus (2012, 2013), we started a series of taxonomical articles in an attempt to fill this gap. So far, in the first two papers of this series (Renaudie \& Lazarus, 2012, 2013), we described forty-five new species: two entactinarians, eight spumellarians and thirty-five nassellarians (including seventeen Plagiacanthidae). Here, we add to this total, twenty-five new forms: six spumellarians and nineteen nassellarians (including no less than sixteen Plagiacanthidae). The remaining forms will be published in a final paper that will close this series.

\section{MATERIAL AND METHODS}

All studied samples (c. 350) come from Ocean Drilling Program (ODP) materials, mostly from the Kerguelen-Heard Plateau (Leg 119, Sites 737, 738, 744, 745 and 746; Leg 120, Sites 747, 748 and 751; Leg 183, Site 1138) with the addition of samples from the Atlantic sector (Leg 113, Sites 689, 690 and 693) (Fig. 1).
Prepared slides were drawn from the junior author's collection, or the Micropaleontological Reference Center (MRC) radiolarian collection hosted by the Museum für Naturkunde in Berlin (Lazarus, 2006). Samples were prepared on random strewn slides using standard methods (Moore, 1973) and $45 \mu \mathrm{m}$ (occasionally 38 and $63 \mu \mathrm{m})$ sieves.

The radiolarian biozonation follows Lazarus (1992) and Abelmann (1992). The age estimates used for the range chart (Fig. 2) are inferred linearly from an age model based on Gersonde et al. (1990) for Leg 113, Barron et al. (1991) for Leg 119, Harwood et al. (1992) for Leg 120 and Bohaty et al. (2003) for Leg 183, with all ages adjusted to the Berggren et al. (1995) time-scale. The relative abundances given in the range chart are drawn from counts made on $45 \mu \mathrm{m}$ strewn slides for 116 of the $c$. 350 samples. Measurements were made on specimen pictures using ImageJ (Abramoff et al., 2004): the range of variation and the mean (between brackets) are both given in micrometres $(\mu \mathrm{m})$ under the Dimensions paragraph for each species.

Higher-level classification largely follows that of Riedel (1967), with a few subsequent emendations as noted individually

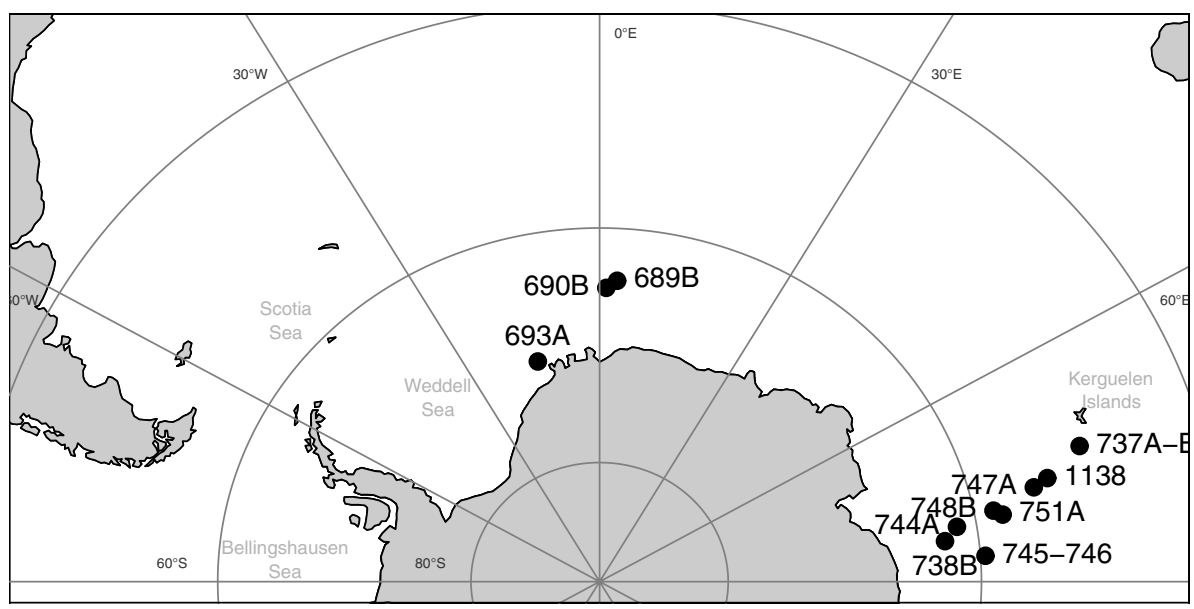

Fig. 1. Location of studied sites. Map created using $\mathrm{R}$ along with package GEOmap (Lees, 2010).

(C) 2015 The Author(s). Published by The Geological Society of London for The Micropalaeontological Society. All rights reserved. For permissions: http://www.geolsoc.org.uk/permissions. Publishing disclaimer: www.geolsoc.org.uk/pub_ethics 


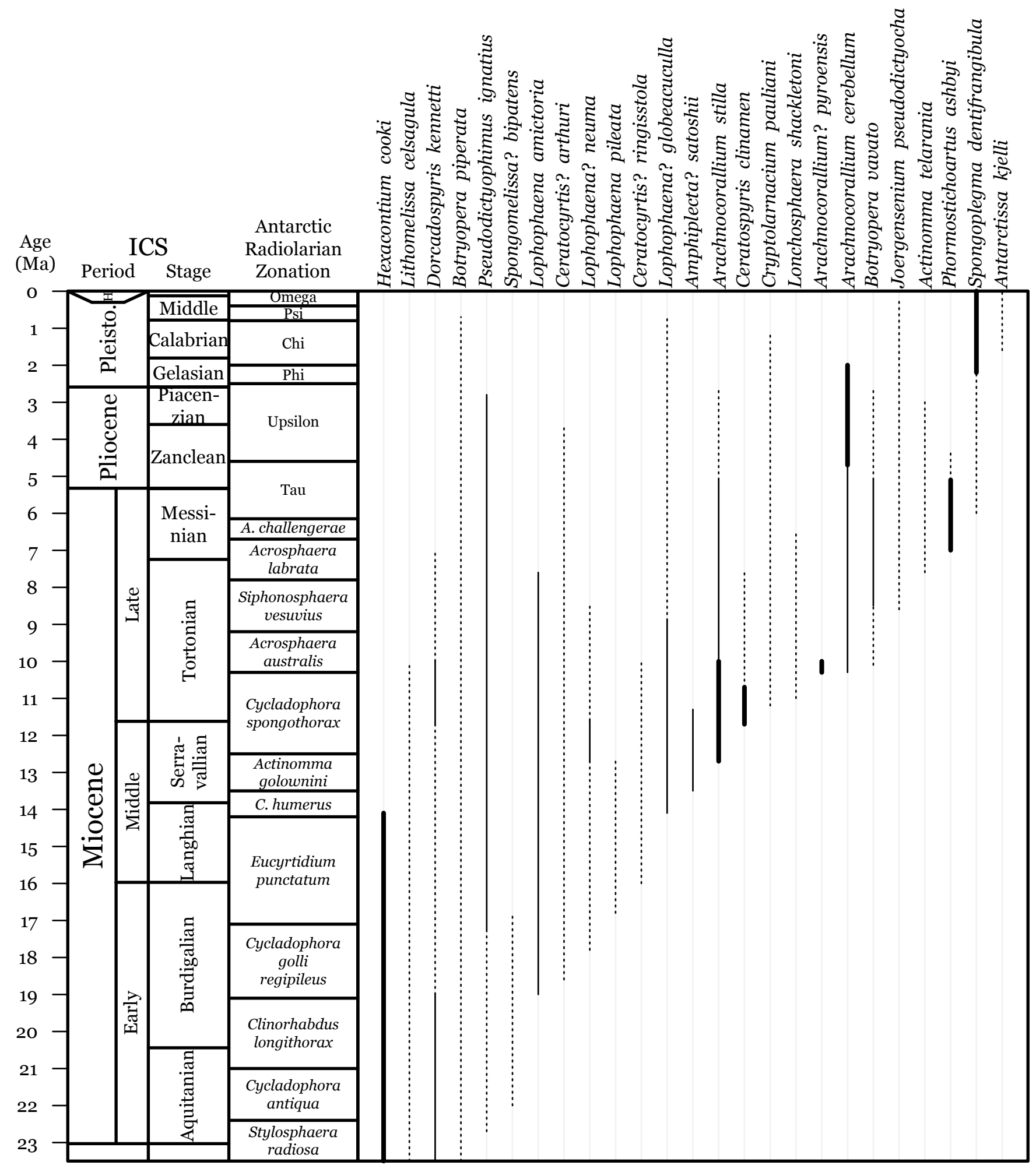

Fig. 2. Range chart of the twenty-five new species described herein. Antarctic radiolarian zonation follows Abelmann (1992) and Lazarus (1992). Numerical age of zonal boundary after Spencer-Cervato (1999). Width of bars corresponds to a rough estimate of the species abundance: dashed line is 'sporadic', plain line 'rare' $(<0.5 \%$ of the assemblages) and bold line 'common' $(>0.5 \%)$. A. challengerae: Amphymenium challengerae; C. humerus: Cycladophora humerus. 
(a)

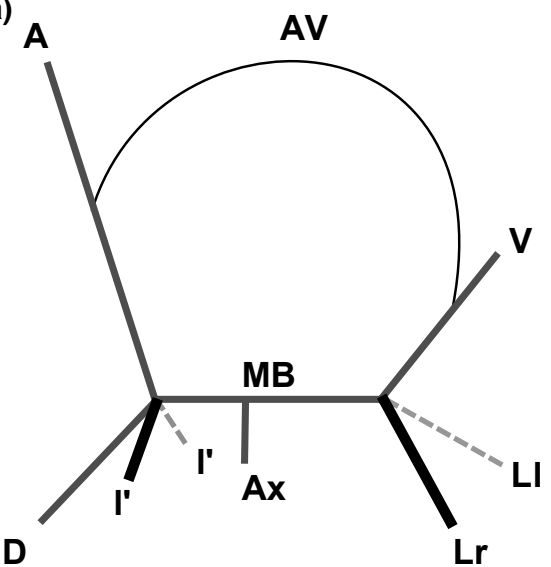

(b)

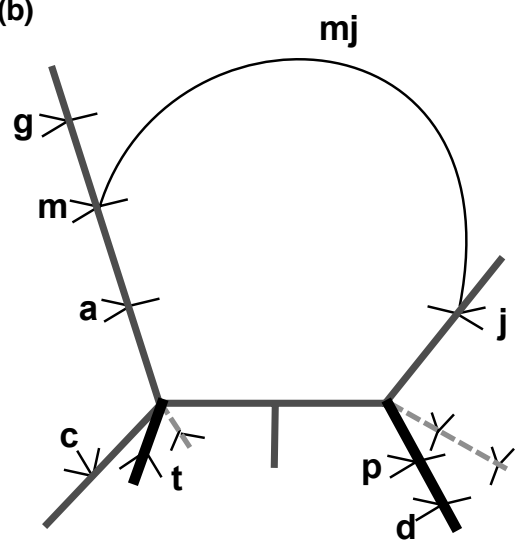

Fig. 3. Schematic illustrations of nassellarian cephalic inner structure. (a) Initial spicule (modified after Jørgensen, 1905). A: apical spine; V: ventral or vertical spine; D: dorsal spine; Lr and Ll: primary lateral right and left spines; l': secondary lateral spines; MB: median bar; Ax: axobate; AV: arch connecting spine $\mathbf{A}$ and spine V. Dark grey: spines in the sagittal plane (i.e. the plane of A, MB, $\mathbf{D}$ and $\mathbf{V}$ ); black: spines on our side of the sagittal plane; dashed, light grey: spines on the other side of the sagittal plane. (b) Apophyses (modified after Petrushevskaya, 1971). g: galear; $m$ : mitral; $a$ : anterior; $t$ : tergal; $c$ : cervical; $p$ : pectoral; $j$ : jugal; $d$ : second series of apophyses on spines $\mathbf{L I}$ and $\mathbf{L r} ; m j$ : arch connecting apophyses $m$ and $j$.

below. The Riedel (1967) classification is based on highly distinct structural features (Baupläne) of the complete shell. Although a more recent, inferred ontogeny-based taxonomical framework has been proposed (De Wever et al., 2001), some authors are in disagreement with it (e.g. Lazarus et al., 2005; Suzuki \& Aita, 2011). Molecular-based classifications of radiolarians, which can perhaps better resolve higher-level relationships, are still in their infancy. Because this work is only about species-level taxonomy we prefer to follow the conservative, less controversial classification of Riedel (1967) whenever possible.

The terminology used here follows mostly Jørgensen (1905) and Petrushevskaya $(1965,1968)$ for nassellarian internal structure (Fig. 3), Goll (1968) for features specific to the family Trissocyclidae and Boltovskoy (1998) for general external characters. The notation for connecting arches in nassellarians follows generally De Wever et al. (1979), Dumitrica (1991) and Funakawa (1995a) in which they are named after a combination of the initials of the spines from which they originate (i.e. arch AV would be an arch connecting spine $\mathbf{A}$ and spine $\mathbf{V}$, see Fig. $3 a)$ or, when necessary, follows Petrushevskaya $(1965,1968)$ in which they are named after the apophyses they are joining (i.e. arch $m j$ joins apophyses $m$ on spine $\mathbf{A}$ and $j$ on spine $\mathbf{V}$, see Fig. 3b)

All holotypes are deposited in the micropalaeontology collection of the Museum für Naturkunde (MfN), Berlin (MfN accession numbers ECO-xxx). Specimens are identified by a circle on the slide. All discussed specimens are illustrated in Plates 1-8.

\section{SYSTEMATIC PALAEONTOLOGY}

Phylum Rhizaria Cavalier-Smith, 2002

Class Radiolaria Müller, 1858

Superorder Polycystinea Ehrenberg, 1838 emend. Riedel, 1967

Order Spumellaria Ehrenberg, 1876

Family Actinommidae Haeckel, 1862 emend. Sanfilippo \& Riedel, 1980

Genus Actinomma Haeckel, 1862 emend. Bjørklund, $1976 b$
Type species. Haliomma trinacrium Haeckel, 1860.

Actinomma telarania $\mathrm{n}$. sp.

(P1. 1, figs $1 \mathrm{~A}-3 \mathrm{C})$

Derivation of name. From the occitan telaranha (pronounced telarania), meaning 'spider web', after the anastomosed outer cortical shell.

Diagnosis. Shell ratio of 1:2:6:7; long, conical spines; thin, anastomosed outermost cortical shell.

Holotype. Plate 1, fig. 1A-B; sample 120-751A-4H-6, 98-102 cm (Early Pliocene); ECO-066.

Material. Eight specimens were observed in samples from ODP sites 690, 693, 744, 747, 751 and 1138 .

Description. Four-shelled actinommid with two medullary and two cortical shells. Innermost shell is polyhedral; outer medullary shell is globular. Three or four (?) beams protrude from the outer medullary shell, join the cortical shells and protrude outside as long, conical spines. Three or four (?) additional by-spines, similar in shape and size to the beams, protrude directly from the inner cortical shell. Inner cortical shell is spherical, thick and bears large circular pores surrounded by hexagonal frames with raised apices. Those raised apices extend as needle-like by-spines, diverge distally into several thin bars parallel to the inner cortical shell, and anastomose to form the outer cortical shell.

Dimensions. (Based on 5 specimens.) Diameter of inner cortical shell: 95-153 (114); of outer medullary shell: 40-55 (44); of inner medullary shell: 13-22 (17).

Occurrence. Sporadic from the Siphonosphaera vesuvius Zone to the Upsilon Zone (Late Miocene to Early Pliocene).

Remarks. Actinomma telarania differs from Actinomma kerguelensis Caulet, 1991 and A. livae Goll \& Bjørklund, 1989 in its long conical spines and its outermost shell being constituted of thin anastomosed material. It also differs from these species in its 
shell ratio. It is distinguished from other actinommids in the presence of an outer cortical shell, and from the species described as Cromyechinus icosacanthus Haeckel, 1887, C. dodecacanthus Haeckel, 1887 and C. circumtextum Haeckel, 1887 primarily in its long conical spines but also in the pore patterns of its shells and, for $C$. circumtextum, in its shell ratio.

Differentiation between immature (juvenile) specimens of this new species and immature specimens of Sphaeroyple robusta Kling, 1973 could be problematic as the three first shells are remarkably similar in both those species (see, for instance, Suzuki, 2006, fig. 11), the only true difference at this stage being the long conical spines of $A$. telarania that seem to appear quite early in the ontogeny of the species: the specimen in Plate 1, fig. 1A-B, whose outermost cortical shell has just started to form, already possesses fully developed conical spines. More juvenile specimens were not recognized in our material, making it difficult to judge when this character appears in regard to the formation of the third shell.

Genus Hexacontium Haeckel, 1881

Type species. Hexacontium phaenaxonium Haeckel, 1887.

Hexacontium? cooki $\mathrm{n}$. sp.

(P1. 3, figs 4A-7)

Derivation of name. Named after the explorer Captain James Cook.

Diagnosis. Large and thick-walled, slightly flattened spherical shape, cortical shell with large pores; six radial beams; numerous thorns.

Holotype. Plate 3, fig. 6; sample 119-744A-10H-1, 60-62 cm (Early Miocene); ECO-067.

Material. 420 specimens observed in samples from ODP Sites 690, 744, 747, 748 and 751.

Description. Large three-shelled actinommid with a shell ratio of approximately $1: 2.5: 10$. Cortical shell is thick, with a circular to somewhat flattened circular outline, and is covered with fairly long, conical thorns arising from bar nodes. Pores on the cortical shell are large and closely packed (see Pl. 3, fig. 4A); they are elliptical to irregular in shape. Outer medullary shell has a somewhat flattened circular outline (see Pl. 3, figs 4B-5). Pores in the medullary shell are small, closely packed (usually arranged in a hexagonal pattern; Pl. 3, fig. 7) and polygonal. Inner medullary shell seems to be a polyhedron (Pl. 3, figs 5-6). Six radial beams arise from this polyhedron, join the outer medullary shell, where they become tribladed, extend to the cortical shell and then protrude as conical spines of same length and shape as the numerous thorns covering the cortical shell.

Dimensions. (Based on 4 specimens.) Diameter of cortical shell: 199-220 (213); of outer medullary shell: 48-66 (55); of inner medullary shell (based on 3 specimens): 15-23 (20).

Occurrence. Common from the Stylosphaera radiosa to the Cycladophora humerus Zone (Late Oligocene to Middle Miocene).
Remarks. This species shares many common features with Actinomma golownini Petrushveskaya, 1975 (= A. tanyacantha Chen, 1975; concerning the priority between Chen (1975) and Petrushevskaya (1975) species names, see Lazarus (1990, p. 710)) such as the shape, size and porosity of their medullary shells and their cortical shell outline. However, they differ in A. golownini having a thinner cortical shell bearing four supplementary spines similar to the six radial ones and in H.? cooki having a thick cortical shell bearing numerous thorns and being larger. This species is also very similar to the Arctic species Hexalonche esmarcki Goll \& Bjørklund, 1989 but varies from it in its larger, thicker and 'thornier' cortical shell. Pores on the cortical shell of H.? cooki are also more regularly disposed and its outer medullary shell is flattened. It also differs from Actinomma haysi Bjørklund, $1976 b$, in possessing numerous thorns, in the shape of the cortical and outer medullary shells and in the conical spines. The cortical shell of H.? cooki is also comparable to that of Cenosphaera coronatoformis Shilov, 1995 and Pentactinosphaera hokurikuensis (Nakaseko, 1955) in its size, thickness and the shape and disposition of its pores; it differs, however, from these species in the presence of numerous thorns and in their outer medullary shell being, in C. coronatoformis, non-existent or, in P. hokurikuensis, a heteropolar, pyriform meshwork of thin bars. Finally, it differs from Haliomma? immensa Kozlova in Petrushevskaya \& Kozlova, 1979 primarily in the radial beams being, in the latter, irregularly distributed and thin as well as conical, and from Haliomma? extima Petrushevskaya in Petrushevskaya \& Kozlova, 1979 in the shell ratio, the greater irregularity in the pore disposition in the latter and the outline of the cortical shell.

Because of its three-shelled skeleton and its six radial beams, $H$.? cooki was tentatively assigned to the genus Hexacontium; however, the tetrapetaloid structure of the inner medullary shell, typical of that genus, could not be observed due to the thickness of the cortical shell. This generic assignment is also problematic considering the fact that the genotype (H. phaenaxonium) was not illustrated by Haeckel and not found during the exploration of Haeckel's material (Aita et al., 2009).

As is summarized in Burridge \& Bjørklund, (2014, p. 78), there is something of a controversy as to whether some Cenozoic and Quaternary genera (including the genera Hexacontium, Pentactinosphaera, Lonchosphaera and Joergensenium that we mention in this series of papers) should be considered to be entactinarians or spumellarians: while some authors (e.g. Dumitrica, 1985; De Wever et al., 2001) think their innermost medullary shell structure is homologous with the spicular inner shell of the entactinarians, other authors (e.g. Suzuki \& Aita, 2011) tend to think that the order Entactinaria became extinct during the Mesozoic. While we do recognize the Cenozoic family Orosphaeridae to be a possible member of the order Entactinaria (as indicated in Renaudie \& Lazarus, 2012), we are not convinced that the innermost shell of the Cenozoic genera mentioned above and the spicular inner shell of the entactinarians are indeed homologous. It is probable that studies on molecular phylogeny of radiolarian families will help in clarifying the matter in the near future, but in the meantime we prefer to think of those genera as belonging to the Spumellaria.

Genus Joergensenium Bjørklund et al., 2007 

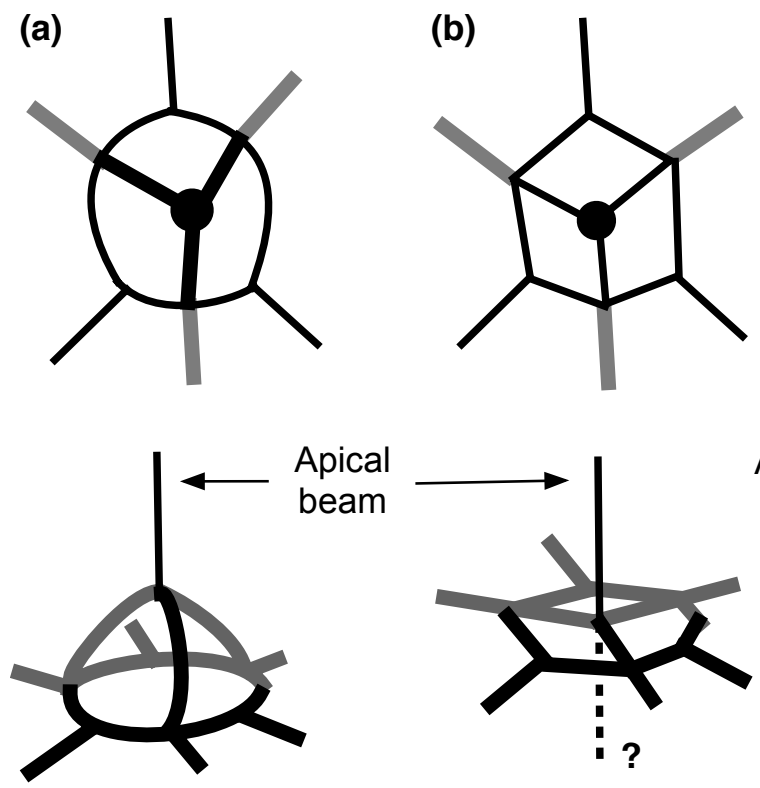

\section{Apical
beam}

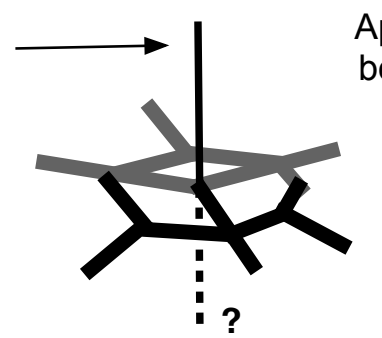

(c)
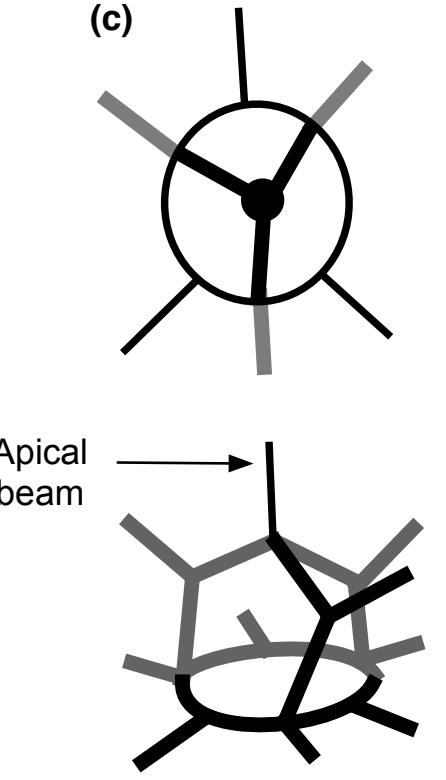

Fig. 4. Schematic representation of the medullary shell of: (a) Lonchosphaera spicata Poposfky, 1908 (modified after Petrushevskaya, 1975). (b)

Joergensenium pseudodictyocha $\mathrm{n}$. $\mathrm{sp}$. (after specimens illustrated in Pl. 1, figs 4A-5B). (c) Lonchosphaera shackletoni n. sp. (after specimens illustrated in $\mathrm{Pl}$. 2, figs $3 \mathrm{~A}-4 \mathrm{C})$. Top: view from above; bottom: oblique view from the front.

Type species. Joergensenium rotatile Bjørklund et al., 2007.

Joergensenium pseudodictyocha $\mathrm{n}$. sp.

(P1. 1, figs 4A-5B, 7A-B; text-fig. 4b)

Derivation of name. After the resemblance of this species' medullary shell with species of the silicoflagellate genus Dictyocha.

Diagnosis. Spicular inner shell; thin outer shell; high shell ratio.

Holotype. Plate 1, fig. 4A-B; sample 113-689B-3H-2, 148-150 $\mathrm{cm}$ (Late Miocene); ECO-050, circle 2.

Material. Ten specimens observed from ODP sites 689, 748, 751 and 1138 .

Description. Small globular outer shell consisting of a meshwork of thin, anastomosed bars diverging from the small, thin spines extending from the silicoflagellate-looking, spicular inner medullary shell, which consists of a somewhat hexagonal ring from which arise six radial beams (in the plane of the ring; P1. 1, fig. 7A; Fig. 4), and of three (Pl. 1, fig. 5B) bars starting from opposite sides of the ring and joining in the middle where one (two?) beam(s) arises perpendicularly to the plane of the ring ( $\mathrm{Pl}$. 1, fig. 5A). The shell ratio is approximately $1: 2$. Some small, thin by-spines arise from some bar nodes of the outer shell, but do not seem to be connected with the inner medullary shell ( $\mathrm{Pl}$. 1, figs 4A, 5B, 7B). Pores on the outer shell are polygonal (generally pentagonal or hexagonal; Pl. 1, figs 4B, 7B) and relatively large compared to the thickness of the bars separating them. There are generally 6 to 8 such pores on a half-equator.

Dimensions. (Based on 3 specimens.) Diameter of outer shell: 44-46 (45); diameter of inner medullary shell: 18-24 (21).

Occurrence. Sporadic from the Siphonosphaera vesuvius Zone (Late Miocene) to the Omega Zone (Pleistocene).

Remarks. This species differs from Lonchosphaera spicata, L.? suzukii and L. shackletoni in its highly reduced size and its

subsequently high shell ratio. The outer shell wall is otherwise very similar to that of L. spicata. J. pseudodictyocha shares many features with Sethostaurus parvulus Popofsky, 1912 (size, shell ratio, shape and porosity of the outer shell) but differs from it in lacking the four long tribladed spines arising from the radial beams of $S$. parvulus. It differs also from Melittosphaera magnaporulosa (Clark \& Campbell, 1942 ) in the latter having a properly latticed cortical shell wall and a spherical, latticed-wall medullary shell; from Haliomma sp. Tan, 1993 in lacking the long radial spines and by-spines; from Actinomma cocles Renaudie \& Lazarus, 2013 in its spicular medullary shell. Actinomma(?) sp. B Hull, 1996 (pl. 1, figs 3-4, 9, 12) seems to have the same medullary shell as $J$. pseudodictyocha and their cortical shell are also very similar; however, the specimen in Hull, (1996) has a lower shell ratio and longer, more numerous spines.

$J$. pseudodictyocha is very similar to the medullary shells of $J$. rotatile Bjørklund et al., 2007 and J. appolo Kamikuri, 2010; however, it differs from them quite clearly in their outer medullary shell consisting of seven cupolas, whereas the external shell of $J$. pseudodictyocha is simply spherical to slightly globular and does not show such cupolas.

Because of their size, it is possible that the two shells of this new species are indeed an outer and an inner medullary shell. Whether this species lacks a cortical shell or all specimens observed are juvenile or broken cannot be determined with certainty.

Genus Lonchosphaera Popofsky, 1908

Type species. Lonchosphaera spicata Popofsky, 1908.

Lonchosphaera shackletoni n. sp.

(P1. 2, figs 3A-5B; text-fig. 4c)

Derivation of name. Named after the polar explorer Sir Ernest Shackleton.

Diagnosis. Large irregular-pored cortical shell; polyhedral medullary shell with radial beams extending externally as long, tribladed spines. 

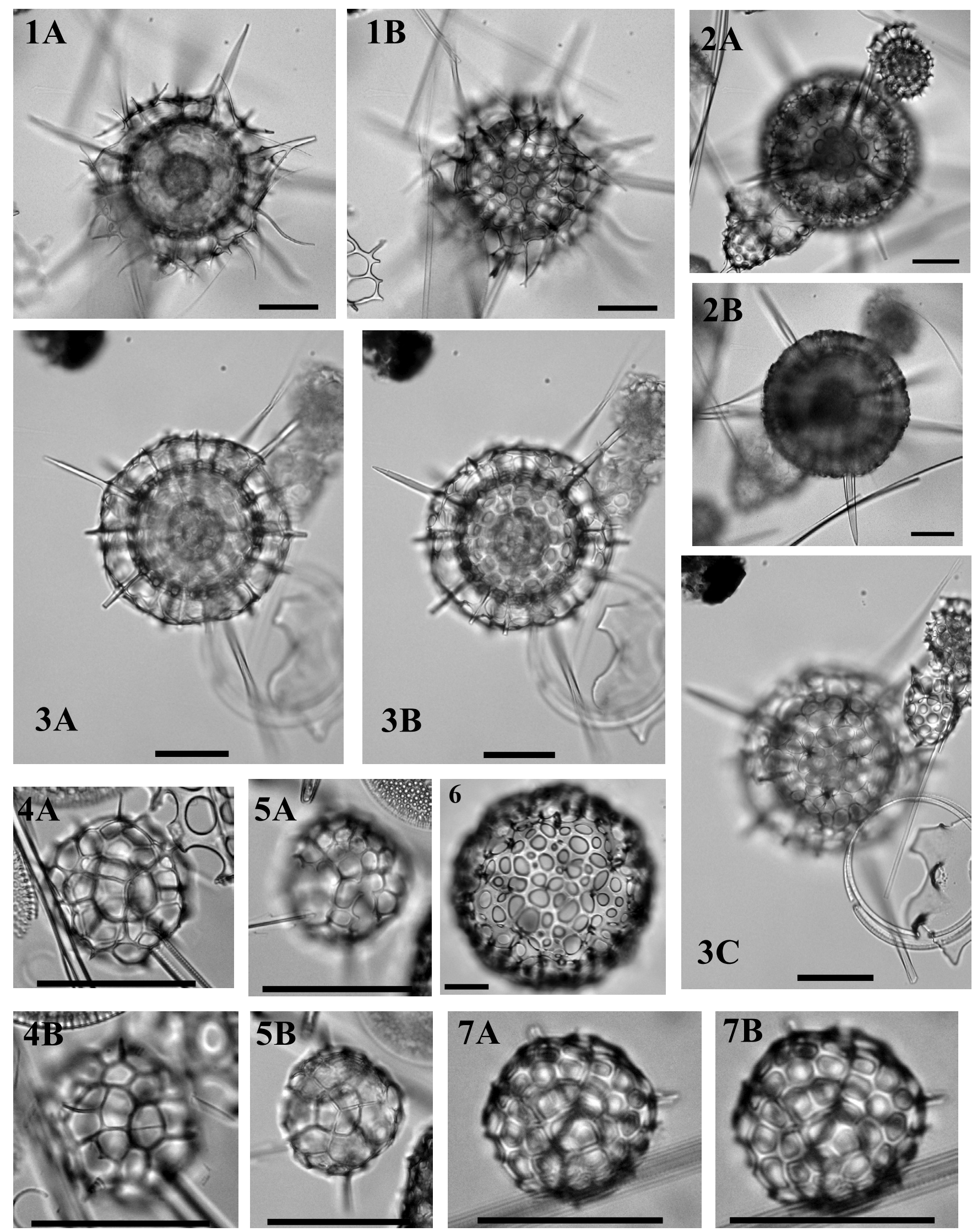
Holotype. Plate 2, fig. 4A-C; sample 183-1138A-13R-2, 20 $22 \mathrm{~cm}$ (Late Miocene); ECO-068.

Material. Eight specimens observed in samples from ODP sites 690 and 1138.

Description. Large, spherical cortical shell with rough surface and numerous pores that are irregular in size, shape and randomly arranged. The bars between pores are rather thin. Cortical shell bears numerous thorns. A small number (two to eight) of long, tribladed spines also protrude from the cortical shell. They originate directly from the beams (text-fig. 4c) arising from the small irregular polyhedral medullary shell. In some specimens, a very thin meshwork links the beams somewhere between the cortical and medullary shells.

Dimensions. (Based on 4 specimens.) Diameter of the cortical shell: 166-192 (179); of the medullary shell: 18-22 (20).

Occurrence. Sporadic from the upper Cycladophora spongothorax Zone to the Siphonosphaera vesuvius Zone (Late Miocene).

Remarks. The medullary shell of Lonchosphaera shackletoni seems to be exactly similar to the one illustrated for $L$. spicata by Petrushevskaya (1975, pl. 17, fig. 8), hence the generic assignment. Although L. shackletoni is also very similar in structure with the specimens illustrated by Petrushevskaya (1975) as $L$. sp. B and $L$. sp. C (respectively her pl. 17, figs $9-10$ and 11-15), the size of the cortical shell, the medullary to cortical shell ratio and the shape of the radial beams in these species are very different. L. shackletoni and L.? suzukii Renaudie \& Lazarus, 2013 differ in the size of their cortical shell, in the tribladed radial spines and in the pore to bar area ratio of the cortical shell. The cortical wall in L.? suzukii is furthermore properly latticed whereas it is somewhat anastomosed as a 3D mesh in L. shackletoni. Additionally, it differs from the specimen illustrated as Octodendron hamuliferum Hollande \& Enjumet, 1960 (in Tan, 1993, pl. 4, fig. 3 non figs 1-2) in the size of the cortical shell and in the radial spines being in the latter larger and serrated, with many small apophyses branching regularly from them.

Genus Spongoplegma Haeckel, 1881

Type species. Spongoplegma antarcticum Haeckel, 1887.

Spongoplegma dentifrangibula $\mathrm{n}$. sp.

(Pl. 2, figs 1A-2B; Pl. 1, fig. 6)

?1992 Spongoplegma sp. Chen in Lazarus: pl. 5, figs 3-4, non pl. 5, figs 1-2; non Spongoplegma sp. Chen, 1975: pl. 22, figs

$1-2$.
Derivation of name. From the Latin dentifragibulus (who breaks teeth), for the thick cortical shell of this species resembling a hard candy.

Diagnosis. Dense medullary meshwork; shell ratio of $1: 2$; thick latticed cortical shell with large, irregular pores.

Holotype. Plate 2, fig. 1A-B; sample 120-747A-1H-3, 45-47 cm (Pleistocene); ECO-069.

Material. 647 Specimens observed in samples from ODP sites 689, 690, 693, 738, 744, 747 and 1138.

Description. Two concentric shells consisting of a thick, latticed cortical shell and a medullary meshwork connected together by a fairly high number of rather thin, cylindrical (rarely bladed) radial beams. There is a depression on the cortical shell where each radial beam fuses with the shell, thus creating a 'bumpy' surface. Pores on the cortical shell are rounded to elliptical, of variable size (but somewhat large) and unevenly distributed. They are separated by thick, cylindrical bars. The medullary meshwork is twice as small as the cortical shell and is somewhat dense. It has a general spherical shape but has a cupola-shaped extension where the radial beams arise. It seems that the very centre of this medullary meshwork is denser and has a more regular geometrical pattern; but, due to the already substantial density of the outer meshwork, it is difficult to observe it.

Dimensions. (Based on 6 specimens.) Diameter of the cortical shell: 221-293 (260); of the medullary shell: 121-139 (126).

Occurrence. Sporadic from the Tau to the Phi Zone (Early Pliocene to Pleistocene), common from the Phi to the Omega Zone (Pleistocene to Holocene).

Remarks. S. dentifrangibula differs from Spongoplegma antarcticum Haeckel, 1887, S. medianum (Nigrini, 1967) and S. arcadophorum (Haeckel, 1887) in having a thick, latticed cortical shell (compared to a thin meshwork of anastomosed bars). It also differs from S. variabile Nakaseko, 1972 in having a thicker wall, bigger, unequal pores, a smaller but denser medullary meshwork and a 'bumpy' surface. It differs from S. holtedahli (Bjørklund, $1976 a$ ) and S. nipponicum (Nakaseko, 1955) primarily in having a single cortical shell; from Rhizosphaera serrata Haeckel, 1887 and Haliomma capillacea Haeckel, 1887 in its thick cortical shell with wider bars between pores and its larger, denser medullary shell; from Actinomma gigantea Popofsky, 1912 in lacking external spines, in the diameter of its cortical shell (more than $200 \mu \mathrm{m}$ in A. gigantea; Popofsky, 1912) and in the lower number of radial beams.

Explanation of Plate 1. fig. 1. Actinomma telarania n. sp. Sample 120-751A-4H-6, 98-102 cm. Holotype: (A) focus on outer medullary shell; (B) focus on inner cortical shell. fig. 2. Actinomma telarania? Sample 120-751A-4H-4, 98-102 cm: (A) focus on inner cortical shell; (B) focus on medullary shells. fig. 3. Actinomma telarania n. sp. Sample 183-1138A-14R-2, 50-58 cm: (A) focus on inner medullary shell; (B) focus on inner cortical shell; (C) focus on outer cortical shell. fig. 4. Joergensenium pseudodictyocha n. sp. Sample 113-689B-3H-2, 148-150 cm. Holotype: (A) focus on medullary shell; (B) focus on cortical shell. fig. 5. Joergensenium pseudodictyocha $\mathrm{n}$. sp. Sample 113-689B-3H-3, 116-118 cm. Broken specimen: (A) focus on cortical shell; (B) focus on medullary shell. fig. 6. Spongoplegma dentifrangibula $\mathrm{n}$. sp. Sample 120-747A-1H-3, 45-47 cm. fig. 7. Joergensenium pseudodictyocha $\mathrm{n}$. sp. Sample 183-1138A-11R-4, 70-78 cm: (A) focus on medullary shell; (B) focus on cortical shell. All scale bars $50 \mu \mathrm{m}$. Magnification $\times 192$ except 4A-5B, 7A-B $(\times 384)$. 

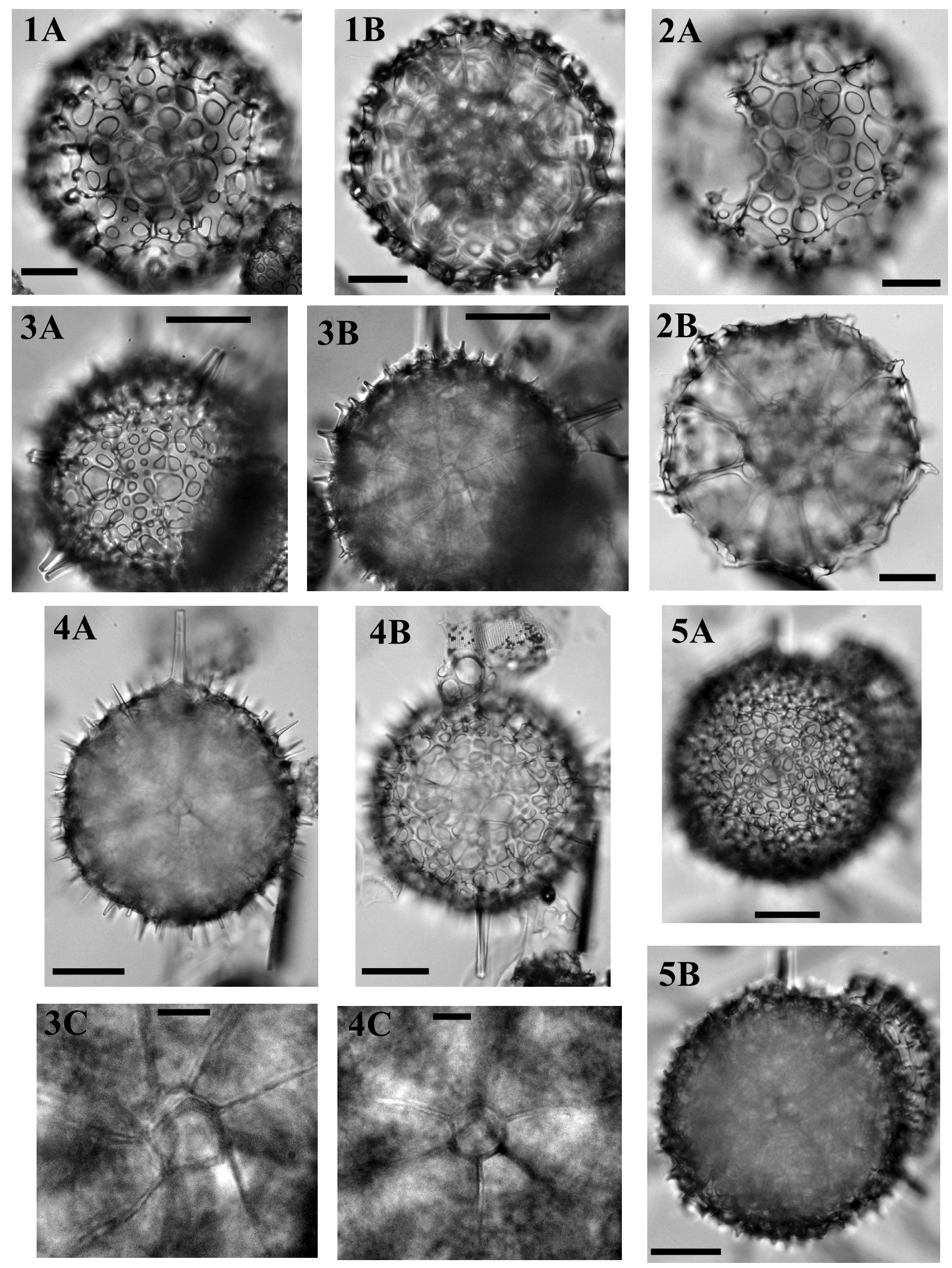
The specimen illustrated as Spongoplegma sp. Chen (in Lazarus, 1992, pl. 5, figs 3-4), although weakly silicified compared to our specimens is likely to be conspecific with our new species. The specimen illustrated by Chen (in Lazarus, 1992) on plate 5, figs $1-2$ as well as the specimens illustrated as Spongoplegma sp. Chen (1975, pl. 22, figs 1-2), although having a slightly irregularly shaped spherical outline, does not seem to have a bumpy surface; they also are more regularly pored, thinner-walled, with a lower shell ratio: they probably both belong to species Spongoplegma variabile Nakaseko, 1972 despite the irregularity of their shell outline.

Family Pyloniidae Haeckel, 1881 Genus Cryptolarnacium Dumitrica, 1989

Type species. Cryptolarnacium hexastylus Dumitrica, 1989.

Cryptolarnacium pauliani $\mathrm{n}$. sp.

(Pl. 3, figs $1 \mathrm{~A}-3 \mathrm{~B}, 8)$

Derivation of name. Named after Paulian Dumitrica, who described the genus, for his contribution to radiolarian research and specifically to the taxonomy of Pyloniidae.

Diagnosis. Two-shelled skeleton with a pyloniid medullary shell; four long conical spines.

Holotype. Plate 3, fig. 2A-C; sample 120-747A-2H-5, 45-47 cm (Late Pliocene); ECO-062, circle 1.

Material. Eleven specimens observed in samples from ODP sites $689,690,747$ and 751.

Description. Small two-shelled skeleton from which arises four very long (up to $180 \mu \mathrm{m}$ ), conical spines. Four additional spines arising also from the medullary shell can be seen on some specimens: these are situated at the bisector of the previously mentioned spines and are considerably smaller and thinner (so much so that they are hardly distinguishable from the other by-spines; Pl. 3, fig. 3A-B). Cortical shell is spherical to ellipsoidal, with small, regularly arranged circular pores and a fair amount of medium-lengthed byspines. Incompletely formed cortical shells appear to be of pyloniid origin (Pl. 3, fig. 1A-B). The medullary shell has an oblong outline and seems to be a pyloniid medullary shell with two opposite gates (P1. 3, figs 1B, 3B). Radial beams extend from it and protrude outside the cortical shell as long conical spines with a thickened base.

Dimensions. (Based on 3 specimens.) Diameter of the cortical shell: $62-70(65)$.

Occurrence. Sporadic from the Cycladophora spongothorax Zone to the Chi Zone (Late Miocene to Pleistocene).
Remarks. Cryptolarnacium pauliani differs from Larnacalpis sp. A Suzuki et al., 2009b, from Larnacalpis sp. 2 Dumitrica, 1989 and from Larnacilla? spp. Dumitrica, 1989 (Dumitrica, 1989, pl. 11, fig. 4, non 3 and 5) in its long conical spines arising from the medullary shell; from Larnacalpis sp. Takahashi \& Honjo, 1981 and from Larnacalpis sp. 1 Dumitrica, 1989 in its more or less spherical outline; and from Tetrapyle octacantha Müller, 1858 in the presence of a cortical shell and of spines. It is also distinguished from Echinomma sphaerechinus Haeckel, 1887, Drymyomma elegans Jørgensen, 1900 and Actinomma cocles Renaudie \& Lazarus, 2013 in its pyloniid medullary shell and in its long conical spines. Finally, it differs from the type species of the genus, the Eocene $C$. hexastylus, in its thinner cortical shell, bearing larger pores, in its numerous by-spines and in the possession of four (instead of six) longer radial spines. Not only does the shell ratio seem lower in $C$. hexastylus, but the overall size of C. pauliani is also much less than C. hexastylus (c. $65 \mu \mathrm{m} \mathrm{v.} c$. $160 \mu \mathrm{m}$ for the cortical shell.).

Order Nassellaria Ehrenberg, 1876

Family Artostrobiidae Riedel, 1967 emend. Foreman, 1973

Genus Phormostichoartus Campbell, 1951 emend. Nigrini, 1977

Type species. Cyrtophormis cylindrica Haeckel, 1887.

Phormostichoartus ashbyi n. sp. (P1. 4, figs 1-3)

Derivation of name. Named after Jeffrey Noel Ashby, for his contribution to Late Neogene radiolarian research.

Diagnosis. Spindle-shaped; four segments; downward-directed ventral tube; 3 to 4 pore rows per segment.

Holotype. Plate 4, fig. 1; sample 119-746A-5H-1, 53-55 cm (Late Miocene); ECO-070.

Material. 489 specimens observed in samples from ODP sites 689, 690, 746, 747, 751 and 1138 .

Description. Four-segmented, spindle-shaped, thick-walled artostrobiid with a short downward-directed ventral tube (in some specimens it appears as a ventral pore; Pl. 4, fig. 3). No externally expressed stricture, although both lumbar and post-abdominal strictures are marked internally. Relatively long, hyaline, invertedtruncated conical peristome. Abdomen and post-abdominal segment are of nearly equal length (peristome excluded) and breadth. The inflexion of the shell outline is on the abdomen. Thorax, abdomen and post-abdominal segment with 3 or 4 pore rows,

Explanation of Plate 2. fig. 1. Spongoplegma dentifrangibula n. sp. Sample 120-747A-1H-3, $45-47 \mathrm{~cm}$ : (A) focus on cortical shell; (B) focus on medullary shell. fig. 2. Spongoplegma dentifrangibula n. sp. Sample 120-747A-3H-1, 45-47 cm: (A) focus on cortical shell; (B) focus on medullary shell. fig. 3. Lonchosphaera shackletoni $\mathrm{n}$. sp. Sample 113-690C-3H-6, 48-54 cm: (A) focus on cortical shell; (B) focus on medullary shell; (C) enlargement of medullary shell. fig. 4. Lonchosphaera shackletoni $\mathrm{n}$. sp. Sample 113-1138A-13R-2, $20-22 \mathrm{~cm}$. Holotype: (A) focus on medullary shell; (B) focus on cortical shell; (C) enlargement of medullary shell. fig. 5. Lonchosphaera shackletoni $\mathrm{n}$. sp. Sample 113-690C-3H-6, 48-54 cm: (A) focus on cortical shell; (B) focus on medullary shell. All scale bars $50 \mu \mathrm{m}$ except for 3C and 4C $(10 \mu \mathrm{m})$. Magnification $\times 192$ except for 4 and $8 \mathrm{~A}-\mathrm{C}(\times 384)$. 

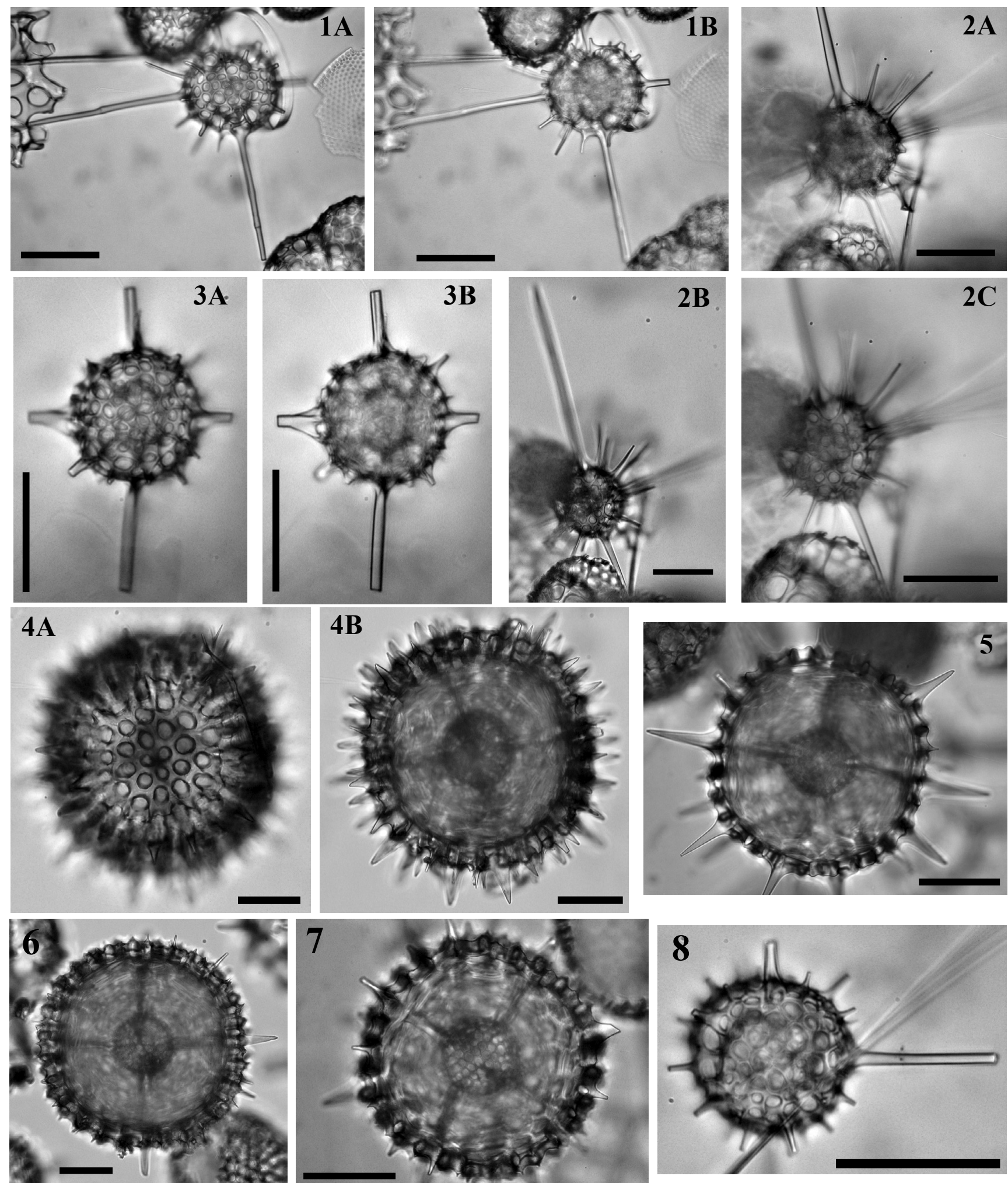

Explanation of Plate 3. fig. 1. Cryptolarnacium pauliani n. sp. Sample 120-747A-2H-5, 45-47 cm: (A) focus on internal structure; (B) focus on shell wall. fig. 2. Cryptolarnacium pauliani $\mathrm{n}$. sp. Sample 120-747A-2H-5, 45-47 cm. Holotype: (A) focus on internal structure; (B) complete specimen; (C) focus on shell wall. fig. 3. Cryptolarnacium pauliani $\mathrm{n}$. sp. Sample 120-747A-3H-1, 45-47 cm: (A) focus on internal structure; (B) focus on shell wall. fig. 4. Hexacontium? cooki n. sp. Sample 113-690B-6H-4, 22-24 cm: (A) focus on cortical shell; (B) focus on outer medullary shell. fig. 5. Hexacontium? cooki? Sample 119-744A-10H-7, 16-18 cm. fig. 6. Hexacontium? cooki n. sp. Sample 119-744A-10H-1, 60-62 cm. Holotype. fig. 7. Hexacontium? cooki $\mathrm{n}$. sp. Sample 119-744A-10H-7, 16-18 cm. fig. 8. Cryptolarnacium pauliani $\mathrm{n}$. sp. Sample 120-747A-2H-1, 45-47 cm. All scale bars $50 \mu \mathrm{m}$. Magnification $\times 384$ except 4A-B, $6(\times 192)$. 
though the lineation on thoracic pores is less regular than on the two following segments. Pores of equal diameter on all segments except on cephalis (where they are smaller).

Dimensions. (Based on 6 specimens.) Total length: 99-139 (107); maximum breadth: 61-80 (66); length of the cephalothorax: 2848 (37); length of hyaline peristome: 16-27 (21).

Occurrence. Common from the Acrosphaera? labrata Zone to the Tau Zone (Late Miocene to Early Pliocene), sporadic from the Tau to the Upsilon Zone (Early Pliocene).

Remarks. It differs from Phormostichoartus corbula (Harting, 1863), P. fistula Nigrini, 1977 and P. pitomorphus Caulet, 1986 in its shell outline, in the smaller number of pore rows per segment and in the length and breadth ratio of the abdomen v. the post-abdominal segment. It differs from other artostrobiids, and in particular from Botryostrobus aquilonaris, in its lower number of segments and the downward direction of its ventral tube. Phormostichoartus sp. A Ashby, 1986 (unpublished thesis, Victoria University of Wellington) differs from this new species only in the inflexion of the outline being on the post-abdominal segment instead of on the abdomen, as is the case in this new species.

Family Plagiacanthidae Hertwig, 1879 emend. Petrushevskaya, 1971

Genus Amphiplecta Haeckel, 1881 emend. Petrushevskaya, 1971 sensu Funakawa, 1994

Type species. Amphiplecta acrostoma Haeckel, 1887.

Amphiplecta? satoshii n. sp.

(Pl. 5, figs 10-12B, 14A-15; Pl. 8, fig. 11)

Derivation of name. Named after Satoshi Funakawa, for his contribution to radiolarian research and particularly to plagiacanthid taxonomy.

Diagnosis. Large, elongated cephalis; dorsal shoulder; short flaring thorax.

Holotype. Plate 5, fig. 11 and Plate 8, fig. 11; Sample 120-751A12H-6, 98-102 cm (Middle Miocene); ECO-071.

Material. Thirty-five specimens observed in samples from ODP sites 748 and 751 .

Description. Dicyrtid with a long, apically-elongated cephalis (some specimens have a somewhat flattened apex; Pl. 5, figs 10-11) and a short, largely flaring thorax. Shell wall is smooth with randomly arranged, well-spaced, small, circular to elliptical pores. A large number of small thorns connected to one another are present at the apex of the cephalis including one broader thorn connected to spine A (see P1. 5, fig. 11). Spine $\mathbf{V}$ is short, and can protrude at the collar stricture as a very short triangular horn (Pl. 5, fig. 10). In some specimens (such as in Pl. 5, fig. 11 and Pl. 8, fig. 11), apophyses $j$ are strongly expressed and bifurcate, one upward, the other downward just before spine $\mathbf{V}$ connects to the wall. Spine $\mathbf{A}$ is fused to the dorsal part of the cephalic wall. An arch AD is well developed, thus creating a small shoulder. Spine D seems to bear some dents
(Pl. 8, fig. 11) in addition to apophyse $c$ which is thin and connects to the arch near its middle. Ax is sometimes seen as a small dent of MB. Spines $\mathbf{L l}$ and $\mathbf{L r}$ join $\mathbf{M B}$ close to spines $\mathbf{A}$ and $\mathbf{D}$ (Pl. 8, fig. 11) and project subhorizontally, almost perpendicularly to the sagittal plan (hence the flaring of the upper thorax). They do not form wings. Arch VL can be seen in some rare specimens as a thin rod. Although the cephalis and the thorax are separated by arches AL and $\mathbf{V L}$, there are no visible furrows along those arches. Arch AL is not distinct but may be embedded in the wall.

Dimensions. (Based on 4 specimens.) Height of the cephalis: 97-116 (105).

Occurrence. Rare from the Actinomma golownini to the lower Cycladophora spongothorax Zones (Middle Miocene).

Remarks. It differs from Amphiplecta tripleura Funakawa, 1995b in the width/length ratio of its cephalis, in having less numerous, smaller pores as well as a smoother shell wall and in the dorsal shoulder being less developed but covered by the shell wall; from A. cylindrocephala Dumitrica, 1973 in the thickness of its wall, the shape of its cephalis and in having less numerous, smaller pores. Contrary to what is seen in A. tripleura and A. acrostoma Haeckel, 1887 (Petrushevskaya, 1971; Funakawa, 1994, 1995b), arch DL (or D-AL according to Funakawa 1995b) is not recognizable in our species, and arch $\mathbf{A L}$ is not distinguishable from the rest of the wall. This renders the genus assignment questionable; however, the fact that arch AD is clearly expressed as a bump external to the rest of the cephalis and the overall shape of the cephalis seems to indicate a close relationship of $A$.? satoshii with those two species.

Amphiplecta? satoshii also differs from Lophophaena galeata Ehrenberg, 1874 (see also Ogane et al., 2009, pl. 79, fig. 1a-c) and L. capito Ehrenberg, 1874 (see also Ogane et al., 2009, pl. 79, fig. 2a-c) in its elongated cephalis with a flattened top, the presence of a cluster of apical spines instead of just a unique spine and, more importantly, in its inner cephalic structure: $L$. galeata seems, based on the Ogane et al. (2009) pictures, to have well-expressed arches ap reminiscent of the ones in Lithomelissa ehrenbergi Bütschli, 1882 (see more in the Description and Remarks section of Lithomelissa celsagula n. sp.).

Genus Antarctissa Petrushevskaya, 1967

Type species. Lithobotrys denticulata Ehrenberg, 1844.

Antarctissa kjelli n. sp.

(Pl. 7, figs 12-13B, 15; Pl. 8, fig. 10)

Derivation of name. Named after Kjell Rasmus Bjørklund for his contribution to radiolarian taxonomy.

Diagnosis. Strawberry-shaped cephalis with, apically, a cluster of supplementary horns; characteristic thorax termination with numerous ridges prolonged as feet, and a large hemispherical, thin sieve plate.

Holotype. Plate 7, fig. 12; sample 120-747A-2H-5, 45-47 cm (Late Pliocene); ECO-031, circle 2. 
Material. Seven specimens observed in samples from ODP site 747.

Description. Large dicyrtid with a cephalis elongated toward its somewhat blunt apex and a long thorax with a short flaring upper part and a lower part in the shape of a pinched cylinder (i.e. a hyperboloid) or, in later form, a proper cylinder (see Pl. 7, fig. 15). Thorax end with several ribs projecting as long, thin teeth. Below this termination is a large, thin, mainly concave sieve plate, perforated by numerous, closely packed, elliptical to polygonal pores.

Spines $\mathbf{A}$ and $\mathbf{V}$ join the wall at the collar stricture. The cephalis, however, exhibits a cluster of apically situated horns (unrelated to any internal spines or apophyses). Spine $\mathbf{D}$ is projected downward and bears an upward-directed apophyse $c$ (evoking a similar disposition typical of genus Antarctissa; compare Pl. 8, fig. 10 with Petrushevskaya (1967, pl. 49, fig. 3)). Spines D, Ll and Lr join the thoracic wall between the upper and the lower thorax and continue outside as short needle-like wings. Spine $\mathbf{A x}$ is situated at the middle of $\mathbf{M B}$ and is fairly long and straight (Pl. 8, fig. 10). Pores on the cephalis are small, of more or less even size and slightly elliptical. Pores on the thorax are generally larger and more unevenly spaced as well as uneven in size. Cephalic wall is thicker and the bars between the pores more frankly crested than on the thorax.

Dimensions. (Based on 5 specimens.) Total length: 124-167 (133); length of cephalis: 35-51 (44); maximum breadth: 73-102 (89).

Occurrence. Sporadic from the Chi to the Omega Zone (Pleistocene to Holocene).

Remarks. Although the overall shape of the species as well as the thorax termination are very uncharacteristic of the genus Antarctissa, the fact that spine A, in particular, joins the cephalis wall at the level of the external collar stricture, and the shape and direction of spine $\mathbf{D}$ together seem to be characters strong enough to justify the assignment of this species to the genus. This species differs from Antarctissa strelkovi Petrushevskaya, 1967 in the shape of the cephalis, the length of the thorax and its peculiar termination. Although Antarctissa strelkovi and A. evanida Renaudie \& Lazarus, 2013 also have clusters of apical horns (systematic in evanida but rarer in strelkovi), they are, in those two species, conical whereas in A. kjelli they are often linked together by blade-shaped connections (see Pl. 7, fig. 12). Finally, this species differs from Helotholus praevema Weaver, 1983 in the shape of its cephalis (H. praevema cephalis being almost hemispherical), in the shoulders of the latter being twice as wide as its cephalis and in the spines $\mathbf{D}, \mathbf{L I}$ and $\mathbf{L r}$ of $H$. praevema joining the wall at the shoulder and never extending outside as wings.

Genus Arachnocorallium Haeckel, 1887 emend. Petrushevskaya, 1971

Type species. Arachnocorallium hexaptera Haeckel, 1887 (Psilomelissa calvata Haeckel, 1887).

Arachnocorallium cerebellum $\mathrm{n}$. sp. (Pl. 5, figs 1-2, 13, 16A-B)
?1990 Peridium longispinum Jørgensen, 1900; Nishimura: pl. 13, fig. 11 non figs $9-10$ c.

Derivation of name. Named after the resemblance of the specimen illustrated in Plate 5, fig. 1 to a brain (from the Latin cerebellum, 'small brain').

Diagnosis. Large, almost spherical, cephalic chamber; strong spines $\mathbf{D}, \mathbf{L I}$ and $\mathbf{L r}$ that branch irregularly in their distal part; several long, subapical by-spines.

Holotype. Plate 5, fig. 2; sample 120-751A-4H-4, 98-102 cm (Early Pliocene); ECO-056, circle 2.

Material. 1396 specimens observed in samples from ODP sites 689, 690, 693, 745, 746, 747, 751 and 1138 .

Description. Shell consists only in a cephalis which is in two distinct parts: a large, spherical, almost globular upper part that bears regularly arranged, relatively large circular pores and whose wall is rough and crested and a more or less conical, narrow lower part with a few large circular pores and a rather smooth wall. Spine A is embedded in the wall of the lower and the upper part and eventually, in some specimens, protrudes as a fairly long conical spine (P1. 5, fig. 2). Spines $\mathbf{D}, \mathbf{L l}$ and $\mathbf{L r}$ are rather strong, relatively long and bifurcate distally. Ax can be seen near the junction of MB, Ll and $\mathbf{L r}$ as a triangular dent on MB. Several supplementary thin, long, conical horns can also be present subapically.

Dimensions. (Based on 6 specimens.) Total length (excluding spines): 80-105 (94).

Occurrence. Rare from the upper Cycladophora spongothorax Zone to the Tau Zone (Late Miocene to Early Pliocene), common from the Tau Zone to the Phi Zone (Early Pliocene to Pleistocene).

Remarks. It differs from Peridium sphaerum Funakawa, 1995b in the presence of the long by-spines and in the robustness, length and shape of the basal spines. It is also distinguishable from the specimen illustrated in Petrushevskaya (1971) as Lophophaeninae gen. sp. cf. Micromelissa coarctata Rüst, 1888 by its size, its numerous, larger pores and the additional spines being confined to the apical part of the cephalis. Psilomelissa? sp. A Hollis, 2002 is lacking an apical horn, has longer, tribladed D, $\mathbf{L l}$ and $\mathbf{L r}$ spines and lacks the basal constriction of the cephalic chamber.

Arachnocorallium stilla $\mathrm{n}$. sp.

(P1. 5, figs 3-5B, 7)

?1996 Arachnocorallium group Motoyama: pl. 3, fig. 17 non fig. 18.

Derivation of name. From the Latin stilla meaning 'drop' (of water), after the outline of the shell.

Diagnosis. Elongated to tear-shaped cephalis; few irregularlyarranged pores, numerous spine-like thorns on upper cephalis.

Holotype. Plate 5, fig. 3; sample 120-745B-14H-6, 98-102 cm (Late Pliocene); ECO-082. 
Material. 336 specimens observed in samples from ODP sites $689,690,693,745,747,748,751,1138$.

Description. Shell consists only of an apically elongated tearshaped cephalis. Pores are circular to elliptical, generally large, irregularly arranged. Shell wall is rough and numerous spine-like thorns arise from bar nodes. Spines $\mathbf{A}$ and $\mathbf{V}$ (Pl. 5, fig. 3) are incorporated in the shell wall but do not seem to protrude as horns (or they are not distinguishable from the numerous thorns). Spines $\mathbf{D}, \mathbf{L l}$ and $\mathbf{L r}$ are fairly long, conical and can bifurcate close to their base (P1. 5, fig. 5). Ax is not noticeable.

Dimensions. (Based on 4 specimens.) Total length (excluding spines): 69-92 (82).

Occurrence. Common from the Actinomma golownini Zone to the Acrosphaera australis Zone (Middle to Late Miocene), then rare until the Tau Zone (Early Pliocene) and finally sporadic until the Upsilon Zone (Late Pliocene).

Remarks. It differs from Peridium infundibuliforme (Funakawa, $1995 b$ ) in its upper cephalis bearing numerous spines, being crested, with a smaller number of pores. This new species also differs in spines $\mathbf{D}, \mathbf{L l}$ and $\mathbf{L r}$ being more robust and longer than in P. infundibuliforme. It is also distinguished from Plectacantha oikiskos Jørgensen, 1905, Arachnocorys dubius Dogiel in Dogiel \& Reshetnyak, 1952, Plectacantha cresmatoplegma Nigrini, 1968 and Plagiacantha panarium Dumitrica, 1973 primarily by those species' cephalic wall being only a thin meshwork spread between a series of spines connected to $\mathbf{M B}$ and directed upwards and not a proper eucephalic chamber as in A. stilla. It differs from Peridium longispinum Jørgensen, 1900 (see also Bjørklund 1976a, pl. 7, figs 9-15) in its elongated cephalis, thicker bars, shorter spines and in being much larger (c. $80 \mu \mathrm{m} \mathrm{v.} \mathrm{c.} 45 \mu \mathrm{m})$; and from Peridium piriforme Popofsky, 1908 also in its larger size $(P$. piriforme is c. $60 \mu \mathrm{m})$ and, more importantly, in its basal spines (D, LI and $\mathbf{L r}$ ) being shorter and lacking the many distal branches that Popofsky described and illustrated for P. piriforme. It is finally distinguished from Arachnocorallium calvata (Haeckel, 1887) by its numerous thorns/spines and in its elongated cephalis.

The specimen illustrated on Plate 5, fig. 5A-B possesses a thin, unfinished thoracic wall, connected to spines $\mathbf{D}, \mathbf{L l}$ and $\mathbf{L r}$ but also to some thorns on the lower third of the cephalic wall (i.e. where the cephalis outline starts to narrow). This growth stage is reminiscent of what has been shown for Arachnocorallium calvata in Petrushevskaya, (1971, pl. 70, figs 1-8); however, in A. calvata, some branchings seem to connect the thorax wall to the upper third of the cephalic wall as well, in an early stage of the thorax development (Petrushevskaya, 1971, pl. 70, fig. 7), whereas here there is no trace of such connections in our specimens of $A$. stilla.

\section{Arachnocorallium? pyroensis $\mathrm{n} . \mathrm{sp}$. (P1. 5, figs 6A-B, 8-9B)}

Derivation of name. From the Latin Pyrois which is another name for the planet Mars, with termination -ensis meaning 'from', pyroensis therefore stands for 'Martian' after the resemblance of the specimen seen in apical view (Pl. 5, fig. 6A-B) with the depiction of Martians in 1960s science fiction.

Diagnosis. Cephalis wall is a loose meshwork attached to a sagittal ring; spines $\mathbf{D}, \mathbf{L I}$ and $\mathbf{L r}$ are long and thin.

Holotype. Plate 5, fig. 9A-B; sample 120-751A-9H-1, 98-102cm (Late Miocene); ECO-065, circle 2.

Material. 412 specimens observed in samples from ODP sites 751 and 1138.

Description. Monocyrtid with a cephalis arranged on both sides of a clearly developed sagittal ring (i.e. A, $\mathbf{V}$ and arch AV; see Pl. 5, fig. 9B). This sagittal ring apex is orientated ventrally. Spines D, Ll and $\mathbf{L r}$ are well developed, long, thin and conical. A supplementary spine projects from spine A dorsally as a short conical horn. Ventrally, a triangular dent can be seen high on spine $\mathbf{V}$. Shell wall is loose, consists of a few large, elliptical pores separated by crested bars. In apical view (see specimen P1. 5, fig. 6A-B), the shell has a cardioid outline due to a constriction following spine $\mathbf{A}$. The breadth (perpendicularly to the sagittal ring) seems on this specimen slightly greater than its width (parallel to the sagittal ring).

Dimensions. (Based on 4 specimens.) Total height (excluding spines): $57-60$ (58).

Occurrence. Common in the Acrosphaera australis Zone (Late Miocene).

Remarks. Despite having what seems to be a sagittal ring, this species is unlikely to be a trissocyclid due to the absence of a basal ring. It differs from members of the genus Zygocircus Bütschli, 1882 and the genus Cortina Haeckel, 1887 in possessing a shell wall and in its well-developed spines D, Ll and Lr. It differs from members of the genus Arachnocorallium in possessing a sagittal ring. The generic assignment is therefore provisional and based on the postulate that the presence of the sagittal ring in this species is only a convergence with the sagittal ring seen in the Trissocyclidae sensu Goll (1979), the Acanthodesmiidae sensu Petrushevskaya (1971) or even the Stephaniidae sensu Nishimura (1990).

Genus Botryopera Haeckel, 1887

Type species. Botryopera cyrtoloba Haeckel, 1887.

Botryopera piperata $\mathrm{n}$. sp.

(P1. 7, figs 6-9B)

Derivation of name. From the Latin piperatus (that contains pepper, i.e. a pepper shaker).

Diagnosis. Thick-walled species of Botryopera with a sieve plate and numerous terminal thoracic teeth in adult specimens; short and wide apical and ventral horns.

Holotype. Plate 7, fig. 7; sample 120-748B-6H-7, $45-47 \mathrm{~cm}$ (Early Miocene); ECO-072.

Material. 100 specimens observed in samples from ODP sites $689,690,693,744,747,748,751$ and 1138. 

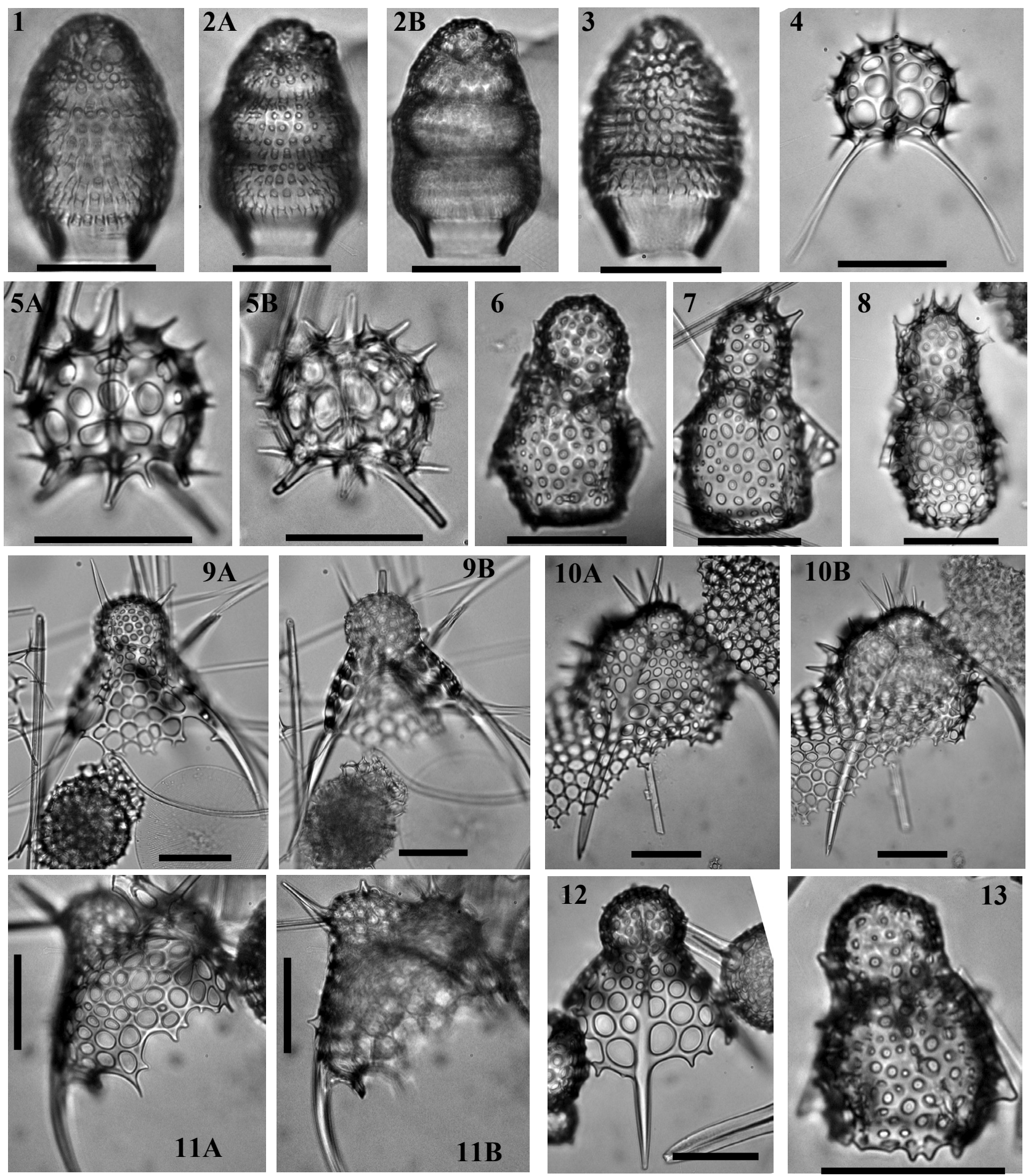

Explanation of Plate 4. fig. 1. Phormostichoartus ashbyi n. sp. Sample 119-746A-5H-1, 53-55 cm. Holotype. fig. 2. Phormostichoartus ashbyi n. sp. Sample 119-746A-5H-3, 53-55 cm: (A) focus on shell wall; (B) focus on shell outline. fig. 3. Phormostichoartus ashbyi n. sp. Sample 120-747A-4H-3 45-47 cm. fig. 4. Dorcadospyris? kennetti n. sp. Sample 120-748B-8H-2, 45-47 cm. Holotype. fig. 5. Dorcadospyris? kennetti n. sp. Sample 120-748B6H-1, 45-47 cm: (A) focus on cephalic wall; (B) focus on $\mathbf{L l}$ and $\mathbf{L r}$. fig. 6. Botryopera vavato n. sp. Sample 119-737A-27X-2, 53-55 cm. fig. 7. Botryopera vavato n. sp. Sample 120-751A-8H-3, 98-102 cm. Holotype. fig. 8. Botryopera vavato n. sp. Sample 120-747A-5H-3, 45-47 cm. fig. 9. Lophophaena? globeacuculla n. sp. Sample 120-748B-5H-7, 45-47 cm. Holotype: (A) focus on cephalic wall; (B) focus on thorax outline. fig. 10. Pseudodictyophimus ignatius $\mathrm{n}$. sp. Sample 120-751A-13H-2, 98-102 cm. Holotype: (A) focus on shell wall; (B) focus on inner structure. fig. 11. Pseudodictyophimus ignatius n. sp. Sample 120-748B-5H-7, 45-47 cm: (A) focus on shell wall; (B) focus on inner structure. fig. 12. Lophophaena? globeacuculla $\mathrm{n}$. sp. Sample 120-747A-7H-5, $45-47 \mathrm{~cm}$. fig. 13. Botryopera vavato n. sp. Sample 119-737A-27X-2, 53-55 cm. All scale bars $50 \mu \mathrm{m}$. Magnification $\times 384$ except for $11 \mathrm{~A}-\mathrm{B}(\times 192)$. 
Description. Dicyrtid with a hemispherical cephalis (c. a third of the shell height) and a truncated conical thorax. Both segments are separated externally by furrows following arches $\mathbf{A L}$ and $\mathbf{V L}$ (P1. 7, fig. 6). Spine $\mathbf{A}$ is fused to the dorsal side of the cephalic wall and protrudes subapically as a short triangular, tribladed, slightly incurved, robust horn. Spine $\mathbf{V}$ protrudes at the collar stricture as a shorter, triangular and tribladed horn. Spines D, Ll and $\mathbf{L r}$ join the thoracic wall, are directed downwards (and eventually form furrows on the thoracic wall; P1. 7, fig. 6) and continue after the thorax termination as small feet. These feet are short and conical and are undifferentiated from the fairly numerous teeth that also project at the thorax termination. The mouth is closed by a sieve plate, relatively thick, perforated by a few, randomly distributed, small circular pores (P1. 7, fig. 9A). Additional robust spines can be present on the cephalis ( $\mathrm{Pl}$. 7, figs 6, 8). The shell wall is generally rather thick. Pores on the cephalis are small and circular while pores on the thorax are somewhat larger.

Dimensions. (Based on 7 specimens.) Total length: 83-103 (94); length of the cephalis: 33-47 (39).

Occurrence. Sporadic from the Stylosphaera radiosa Zone to the Chi Zone (Late Oligocene to Pleistocene).

Remarks. This species is easily distinguished from other species of Botryopera because of the presence of basal teeth and of a sieve plate closing the basal aperture. The thickness of the shell and the short, robust horns are also characteristic of this species. In particular, it differs from Botryopera chippewa Renaudie \& Lazarus, 2013 in the cephalis to thorax height ratio, in its shell outline and the shape and length of the apical horn. It differs from Pseudodictyophimus gracilipes Bailey, 1856 (and in particular to the form described as Pseudodictyophimus gracilipes bicornis (Ehrenberg, 1861); see Petrushevskaya (1967, pl. 41, figs 1-5), Suzuki et al. (2009a, pl. 45, fig. 8a-d)) and from Trisulcus nanus (Popofsky, 1913) emend. Petrushevskaya, 1971 in the absence of wings, the length of the apical horn, the shell thickness and the less-marked shoulders. Cephaluspinus josephinus Alvira Martin, 1971 seems to be very similar to B. piperata as they share their thorax shape and most noticeably their peculiar thorax termination, but they differ in $C$. josephinus having thin, long apical and vertical spines and a more pronounced change of contour at the collar stricture (judging by the specimen illustrated in Alvira Martin, 1971, pl. 3, fig. 2). The specimen illustrated as Botryopera? pseudoantarctissa Petrushevskaya \& Kozlova, 1979 in Hull (1996, pl. 4, figs 3-4) seems similar to $B$. piperata but lacks a sieve plate and robust horns (which can be due to preservation or ontogeny) and has larger, polygonal pores. B. pseudoantarctissa as described and illustrated in Petrushevskaya \& Kozlova (1979) is distinguishable from this new species primarily in having a straight, cylindrical thorax and lacking horns. B. piperata finally differs from Botryopera? chlamyda Petrushevskaya, 1975 primarily in its flaring thorax and smoother wall and from the specimen illustrated as Pseudodictyophimus? sp. indet. in Petrushveskaya \& Kozlova (1972, pl. 37, fig. 22) in lacking wings.

\section{Botryopera vavato $\mathrm{n} . \mathrm{sp}$.}

$$
\text { (P1. 4, figs 6-8, 13) }
$$

Derivation of name. From the Latin vavato, meaning puppet.
Diagnosis. Species of Botryopera with a cylindrical thorax and thin, needle-like $\mathbf{D}, \mathbf{L I}$ and $\mathbf{L r}$ wings.

Holotype. Plate 4, fig. 7; sample 120-751A-8H-3, $98-102 \mathrm{~cm}$ (Late Miocene); ECO-073.

Material. 173 specimens observed in samples from ODP sites $689,690,693,737,747,751$ and 1138 .

Description. Dicyrtid with a hemispherical to ellipsoidal (elongated toward the apex) cephalis and a cylindrical to barrel-shaped thorax. Both are separated externally by furrows along $\mathbf{A L}$ and VL. Spine A is fused to the dorsal side of the cephalic wall while spine $\mathbf{V}$ joins the wall at the collar stricture. Both can protrude as relatively small, barely noticeable needle-like spines. Spines D, LI and $\mathbf{L r}$ in contrast always protrude as long needle-like, downward-directed wings. Some bars can occasionally link the distal part of the wings to the rest of the thorax (see Pl. 4, fig. 7). Thorax termination seems closed. Pores on the cephalis and on the thorax are small, circular to elliptical, and randomly distributed. Cephalis can bear additional small spines (P1. 4, figs 7-8).

Dimensions. (Based on 4 specimens.) Total length: 88-122 (110); length of the cephalis: $37-50$ (46).

Occurrence. Sporadic from the upper Cycladophora spongothorax Zone to the Upsilon Zone (Late Miocene to Late Pliocene), rare from the Siphonosphaera vesuvius to the Tau Zone (Late Miocene).

Remarks. This species is characterized by its wings and its more or less cylindrical, closed thorax. The furrows along arches AL and $\mathbf{V L}$, the shape of the cephalis and the disposition of spines $\mathbf{A}$ and $\mathbf{V}$ relative to the shell wall seem to be characteristic of this group of small dicyrtids that we have regrouped in this series of papers (Renaudie \& Lazarus 2012, 2013) inside the genus Botryopera (with the exception of Botryopera? daleki Renaudie \& Lazarus, 2013 as explained in the Remarks for that species).

This species differs from $B$. piperata and $B$. chippewa Renaudie \& Lazarus, 2013 in its fairly long thorax, its short, weak apical spine and its wings; from Lithomelissa buetschlii Haeckel, 1887 primarily in its wall thickness, in the length of its cephalis and thorax and in the cephalis/thorax ratio; from Dimelissa apis Petrushevskaya, 1971 and the specimens illustrated as Lithopera oceanica Ehrenberg group in Petrushevskaya (1975, pl. 19, figs 4-5) in its long, cylindrical thorax; from Trisulcus nanus (Popofsky, 1913) emend. Petrushevskaya, 1971 primarily in lacking the deep furrows along spines $\mathbf{D}, \mathbf{L I}$ and $\mathbf{L r}$ at the collar stricture; from Lithomelissa setosa Jørgensen, 1900, in the presence of wings, the less marked shoulders and the modest yet present apical horn; from Lophophaenoma arctissa Petrushevskaya in Petrushevskaya \& Kozlova, 1979 in the latter having a thicker shell wall and bearing fewer pores (specimens illustrated in Petrushevskaya \& Kozlova, 1979, figs 339 and 342), in the wings (if any) being poorly developed and in the cephalis-thorax length ratio; from the specimen illustrated as Botryopera laticeps? (Jørgensen) in Petrushevskaya (1975, pl. 20, fig. 3) in the cephalis/thorax ratio and the thorax width; from Antarctissa deflandrei Petrushevskaya, 1975 (=Antarctissa conradae Chen, 1975) in the 

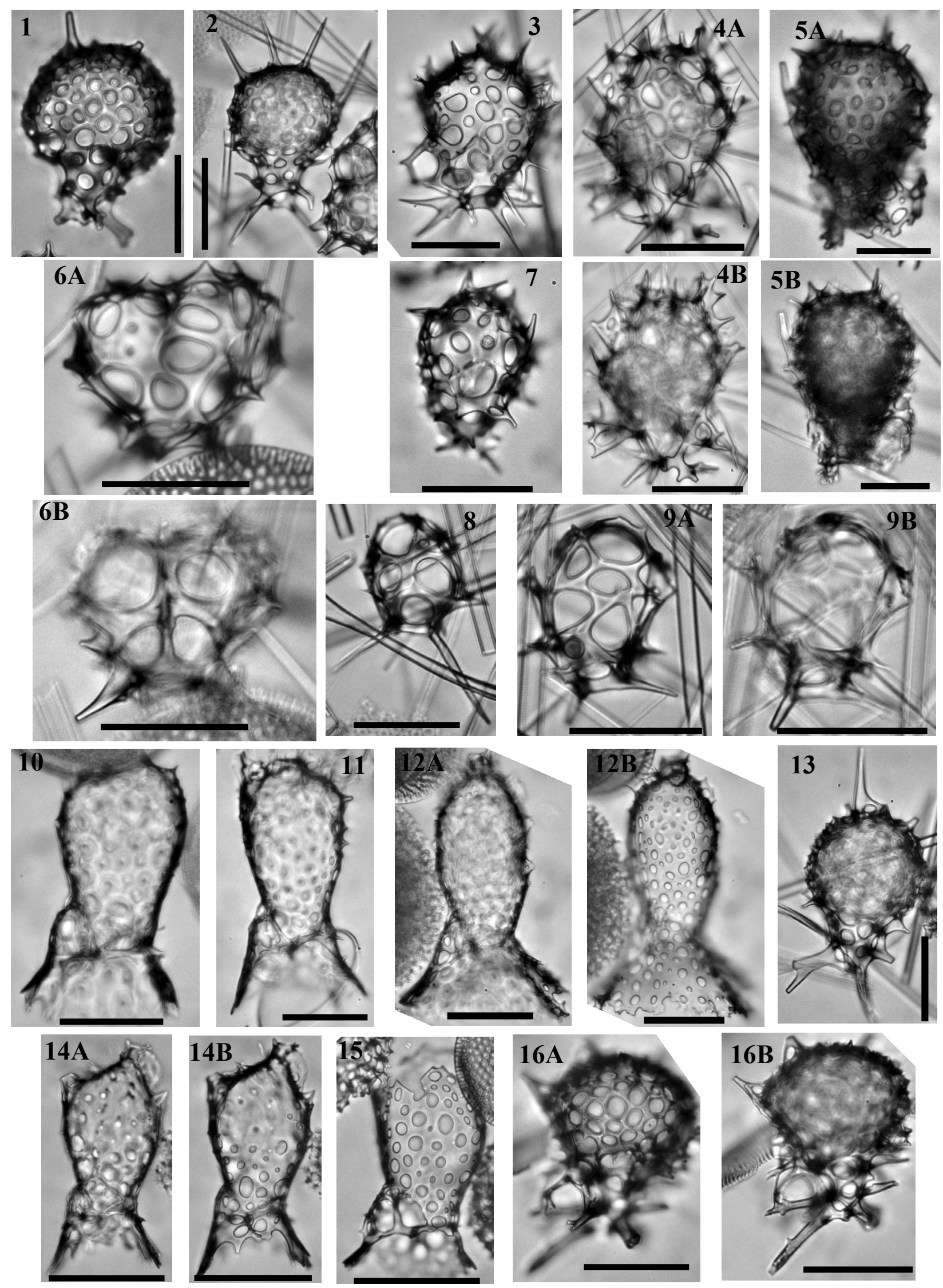
presence of wings, in the latter's spine A joining the cephalic wall at the collar stricture, and in its cephalis apex being round instead of elongated into a peak as in A. deflandrei.

\section{Genus Ceratocyrtis Bütschli, 1882}

Type species. Cornutella cuccularis Ehrenberg, 1874.

Ceratocyrtis? arthuri n. sp.

(P1. 6, figs 4A-B, 6A-B)

Derivation of name. Named after Arthur Popofsky, for his contribution to Antarctic radiolarian research.

Diagnosis. Dome-shaped skeleton; no external distinction between the cephalis and the thorax; all spines connect together halfway down the shell cavity.

Holotype. Plate 6, fig. 6A-B; sample 119-737A-25X-3, 53-55 cm (Late Miocene); ECO-074.

Material. 42 specimens observed in samples from ODP sites 689, $690,693,737,744,745,748,751$ and 1138 .

Description. Small dicyrtid with a cephalis and a thorax indiscernible externally. Thorax seems to be closed by a sieve plate (P1. 6, fig. 4A). Pores on the shell wall are irregular in size, shape (though usually polygonal) and disposition. $\mathbf{M B}$ is reduced to a point from where all spines $(\mathbf{A}, \mathbf{V}, \mathbf{D}, \mathbf{L I}$ and $\mathbf{L r}$ ) project upwards and protrude outside the wall as short conical horns. Some additional spines are present on the cephalis and some of them may be related to apophyses (see P1. 6, fig. 6B). The point where all spines converge, i.e. MB, is situated halfway down the shell cavity, meaning that, technically, the cephalis and the thorax are of equal length.

Dimensions. (Based on the 2 specimens illustrated.): Total height: $62-75$.

Occurrence. Sporadic from the Cycladophora golli regipileus Zone to the Upsilon Zone (Early Miocene to Early Pliocene).

Remarks. Because of the thorax termination and the cephalis length and because the axobate was not observed, the generic assignment of this species to Ceratocyrtis is tentative. The fact that there is no discernible collar stricture and that MB is reduced to a point make us lean toward this assignment. Clathromitra pterophormis Haeckel, 1887 and Clathromitra pentacantha
Haeckel, 1887 also have a highly reduced MB and a domeshaped shell; however, they also have an axobate in the shape of a cluster of lumps, and all major spines protruding as long, robust, tribladed (and panelled, in the case of C. pterophormis) appendages. $C$ ? arthuri is distinguishable from Ceratocyrtis mashae Bjørklund, $1976 a$ in its smaller size, in MB being situated lower in the shell cavity and in the pores being smaller; from C. stoermeri Goll \& Bjørklund, 1989 and C. broeggeri Goll \& Bjørklund, 1989 in its thorax and cephalis being indistinguishable externally.

Ceratocyrtis? ringisstola $\mathrm{n}$. sp.

(Pl. 6, figs 5A-B, 7A-8B).

Derivation of name. From the Latin ringa (hoop) and stola (dress), ringisstola therefore stands for 'dress with hoops', i.e. a crinoline, after the general shape of the shell.

Diagnosis. Large dicyrtid; rim with teeth at thorax termination; small cephalis with internal spicule in a cross pattern.

Holotype. Plate 6, fig. 7A-B; sample 119-744A-7H-3, 53-55 cm (Middle Miocene); ECO-075.

Material. 12 specimens observed in samples from ODP sites 744, 747 and 751.

Description. Large dicyrtid with a reduced cephalis and a long, conical thorax. The collar stricture is not marked externally. Thorax terminates on a rim that bears between 10 and 20 downwarddirected, short, conical spines. Pores on the thorax are large and polygonal. There is a size gradient from the cephalis to the thorax rim for those pores and they seem to be distributed randomly. Numerous thorns arise from bar nodes on the cephalis and the upper thorax. Spines $\mathbf{D}, \mathbf{V}, \mathbf{L I}$ and $\mathbf{L r}$ are of equal length and in the same plane, as a cross (see P1. 6, fig. 8B), while MB is reduced to a point. $\mathbf{A}$ and $\mathbf{A x}$ were not observed (maybe due to the fact that most of the specimens were observed in apical view). Spines $\mathbf{D}, \mathbf{V}$, Ll and Lr protrude outside the wall as horns that are similar in shape and size to the numerous thorns that the wall already bears.

Dimensions. (Based on 4 specimens.) Breadth of thorax termination: 200-226 (221).

Occurrence. Sporadic from the Eucyrtidium punctatum to the upper Cycladophora spongothorax Zone (Middle to Late Miocene).

Explanation of Plate 5. fig. 1. Arachnocorallium cerebellum n. sp. Sample 120-747A-4H-1, 45-47 cm. fig. 2. Arachnocorallium cerebellum n. sp. Sample 120-751A-4H-4, 98-102 cm. Holotype. fig. 3. Arachnocorallium stilla n. sp. Sample 119-745B-14H-6, 53-55 cm. Holotype. fig. 4. Arachnocorallium stilla? Sample 120-751A-2H-3, 98-102 cm: (A) focus on cephalic wall; (B) frocus on MB. fig. 5. Arachnocorallium stilla $\mathrm{n}$. sp. Sample 119-737B-5R-3, 53-55 cm: (A) focus on cephalic wall; (B) focus on MB. fig. 6. Arachnocorallium? pyroensis? Sample 120-751A-9H-1, 98-102 cm. Apical view: (A) focus on cephalic wall; (B) focus on inner structure. fig. 7. Arachnocorallium stilla n. sp. Sample 119-746A-7H-2, 53-55 cm. fig. 8. Arachnocorallium? pyroensis n. sp. Sample 120-751A-9H-1, 98-102 cm. fig. 9. Arachnocorallium? pyroensis n. sp. Sample 120-751A9H-1, 98-102 cm. Holotype: (A) focus on cephalic wall; (B) focus on possible sagittal ring. fig. 10. Amphiplecta? satoshii n. sp. Sample 119-746A7H-2, 53-55 cm. fig. 11. Amphiplecta? satoshii n. sp. Sample 120-751A-12H-6, 98-102 cm. Holotype. fig. 12. Amphiplecta? satoshii n. sp. Sample 120-751A-12H-6, 98-102 cm: (A) focus on inner structure; (B) focus on cephalis wall. fig. 13. Arachnocorallium cerebellum n. sp. Sample 120-751A4H-4, 98-102 cm. fig. 14. Amphiplecta? satoshii n. sp. Sample 120-751A-12H-6, 98-102 cm: (A) focus on inner structure; (B) focus on cephalis wall. fig. 15. Amphiplecta? satoshii n. sp. Sample 120-751A-12H-6, 98-102 cm. Broken specimen showing spine D. fig. 16. Arachnocorallium cerebellum? Sample 119-745B-19H-6, 46-48 cm: (A) focus on cephalis wall; (B) focus on shell outline. All scale bars $50 \mu$ m. Magnification $\times 384$. 

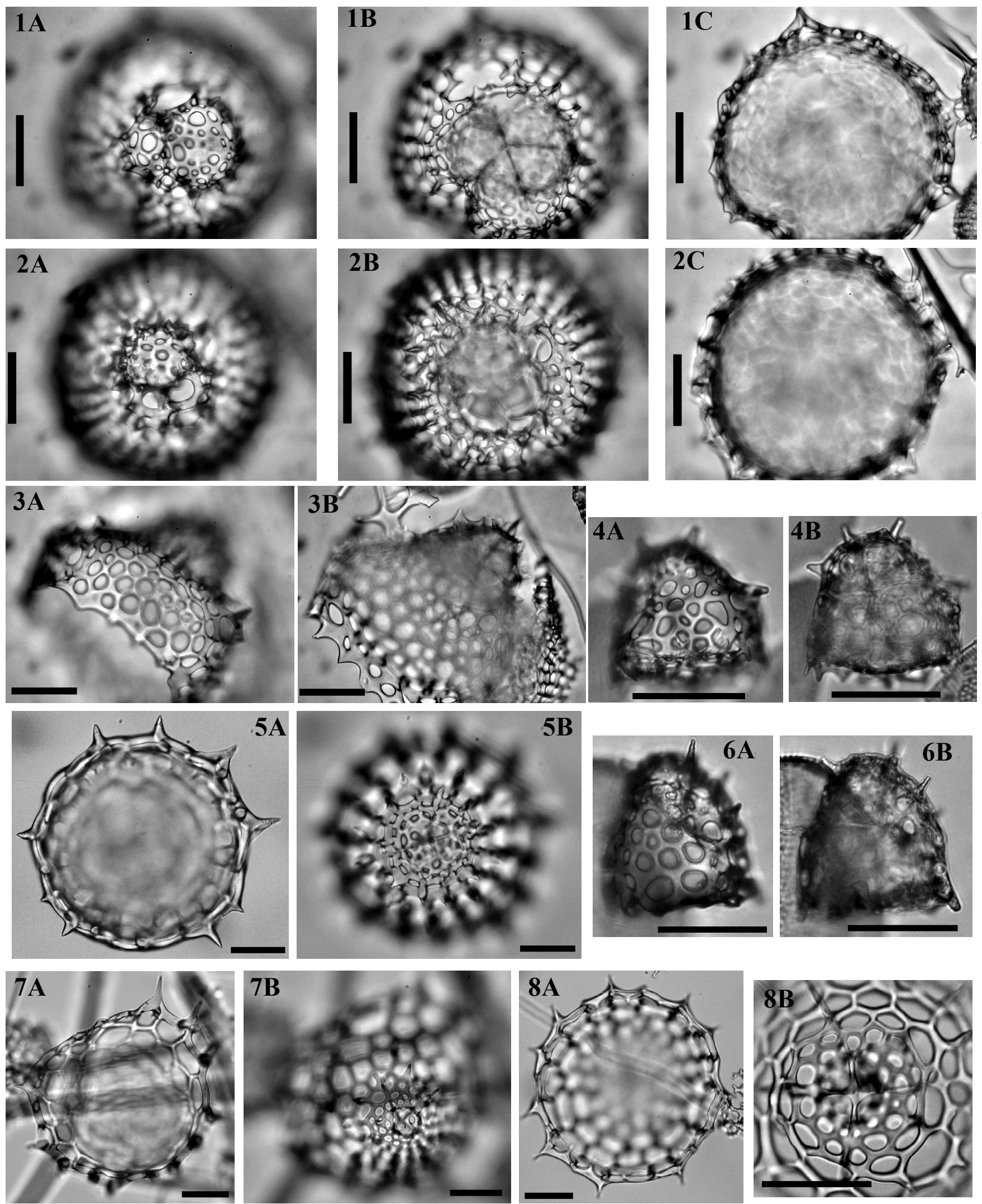
Remarks. The possible absence of an axobate, the thorax termination and the 'cross' disposition of spines $\mathbf{D}, \mathbf{V}, \mathbf{L l}$ and $\mathbf{L r}$ make the assignment to genus Ceratocyrtis questionable. All these characters would fit rather well with species of the genus Lampromitra; however, the reduced size of the cephalis, and the fact that the spines protrude outside as horns do not fit with the description this genus either. The cross disposition of the main spines evokes that typical of the genus Velicucullus Riedel \& Campbell, 1952; however, species of this genus (such as V. oddgurneri Bjørklund, 1976a) generally have a highly flattened shell and relatively large cephalis. Early forms of Velicucullus altus Abelmann, 1990 have a more conical shell; however, the pore size, shape and density on $C$. ringisstola and the size of its cephalis are very unlike that of this species.

Genus Lithomelissa Ehrenberg, 1847

Type species. Lithomelissa microptera Ehrenberg, 1854.

Lithomelissa celsagula $\mathrm{n}$. sp.

(Pl. 7, figs 10A-11B, 14A-B, 16A-B; Pl. 8, fig. 12)

?1971 Lophophaenoma sp. G Petrushevskaya: pl. 56, fig. 17 non fig. 16.

Derivation of name. From the Latin, celsus (high) and gula (throat).

Diagnosis. Three wings; collar stricture follow arches ap; subapical, tribladed horn.

Holotype. Plate 7, fig. 10A-B; sample 120-748B-7H-4, 45-47 cm (Early Miocene); ECO-076.

Material. Six specimens observed in samples from ODP sites 748,751 and 1138 .

Description. Large dicyrtid with a kidney-shaped cephalic chamber and a thorax whose upper part is deformed by three, almost horizontal in some specimens, short, robust wings derived from spines D, Ll and Lr. These wings can be, proximally, linked to the thorax by arches (Pl. 7, fig. 10B). Spine $\mathbf{A}$ is free in the cephalic cavity and protrudes subapically as a tribladed horn. Arches ap are clearly marked (P1. 8, fig. 12). The collar stricture on the dorsal side is situated at the level of apophyse $a$ and follows arches ap. Pores vary widely in size and shape and are randomly distributed. Pores on the cephalis are smaller than on the thorax. Thorax termination is ragged. The shell is generally thin, except in some rare, late specimens (Pl. 7, fig. 11A-B).
Dimensions. (Based on 5 specimens.) Length of the cephalis: $42-$ 66 (53); breadth at wings: 84-102 (91).

Occurrence. Sporadic from the Stylosphaera radiosa Zone to the upper Cycladophora spongothorax Zone (Late Oligocene to Late Miocene).

Remarks. This species differs from Lithomelissa ehrenbergi Bütschli, 1882 in possessing three wings and in being generally larger; however, it shares with this species (see Bütschli, 1882, fig. 21a) and with L. mitra Bütschli, 1882 (see Bütschli, 1882, fig. 24, and Petrushevskaya, 1971, pl. 44, figs 1-2), L. microptera Ehrenberg, 1854 (see Petrushevskaya, 1971, pl. 44, fig. 3), L. macroptera Ehrenberg, 1874 (see Ogane et al., 2009, pl. 4, figs 3a-4d, 7a-d), L. porosa Kozlova, 1999, Lophophaena galeata Ehrenberg, 1874 (see Ogane et al., 2009, pl. 79, fig. 1a-c) and Lophophaena capito Ehrenberg, 1874 (see Ogane et al., 2009, pl. 79, fig. $2 \mathrm{a}-\mathrm{c}$ ) its peculiar collar structure built on arches ap. This structure is to be compared with the structure of the genus Gondwanaria and some species of the genus Lipmanella (see Funakawa, 2000, text-figs 4-7 and pl. 7, figs 3C, 4C and 5C).

Genus Lophophaena Ehrenberg, 1847 sensu Petrushevskaya, 1971

Type species. Lophophaena galeaorci Ehrenberg, 1854.

Lophophaena amictoria $\mathrm{n}$. sp.

(P1. 8, figs 1-3)

1989 Peridium spp. Lazarus \& Pallant: pl. 2, fig. 15 non figs 13-14, 16.

Derivation of name. From the Latin adjective amictorius (designing pieces of cloth that can be worn as a scarf), after the 'neck'structure of this species.

Diagnosis. Globular cephalis, diagonal inflated collar structure and three feet.

Holotype. Plate 8, fig. 2; sample 119-746A-7H-2, 53-55 cm (Late Miocene); ECO-077.

Material. 110 specimens observed in samples from 689, 690,693, $744,746,748,751,1138$.

Description. Spines $\mathbf{A}$ and $\mathbf{V}$ are free in the cephalic cavity and are both projected upwards (they form together an angle of $c$. $\left.45^{\circ}\right)$. They both protrude as short conical horns. MB is short and inclined toward spines $\mathbf{V}, \mathbf{L l}$ and $\mathbf{L r}$. Spines $\mathbf{D}$, Ll and

Explanation of Plate 6. fig. 1. Spongomelissa? bipatens n. sp. Sample 120-748B-8H-2, 45-47 cm. Holotype, apical view: A-C. fig. 2. Spongomelissa? bipatens $\mathrm{n}$. sp. Sample 120-748B-8H-2, 45-47 cm. Apical view: A-C. fig. 3. Spongomelissa? bipatens n. sp. Sample 120-748B-8H-2, 45-47 cm: A, B. fig. 4. Ceratocyrtis? arthuri n. sp. Sample 119-737A-25X-3, 53-55 cm: (A) focus on cephalic wall; (B) focus on inner structure. fig. 5. Ceratocyrtis? ringisstola $\mathrm{n}$. sp. Sample 119-744A-8H-1, 53-55 cm. Apical view: (A) focus on thorax termination; (B) focus on apex. fig. 6. Ceratocyrtis? arthuri n. sp. Sample 119-737A-25X-3, 53-55cm. Holotype: (A) focus on cephalic wall; (B) focus on inner structure. fig. 7. Ceratocyrtis? ringisstola n. sp. Sample 119-744A-7H-3, 53-55 cm. Holotype, tilted apical view: (A) focus on thorax termination; (B) focus on apex. fig. 8. Ceratocyrtis? ringisstola n. sp. Sample 119-744A-8H-1, 53-55 cm. Basal view: (A) focus on thorax termination; (B) focus on inner structure. All scale bars $50 \mu \mathrm{m}$. Magnification $\times 384$ except for 5 A-B, 7 A-8B $(\times 192)$. 

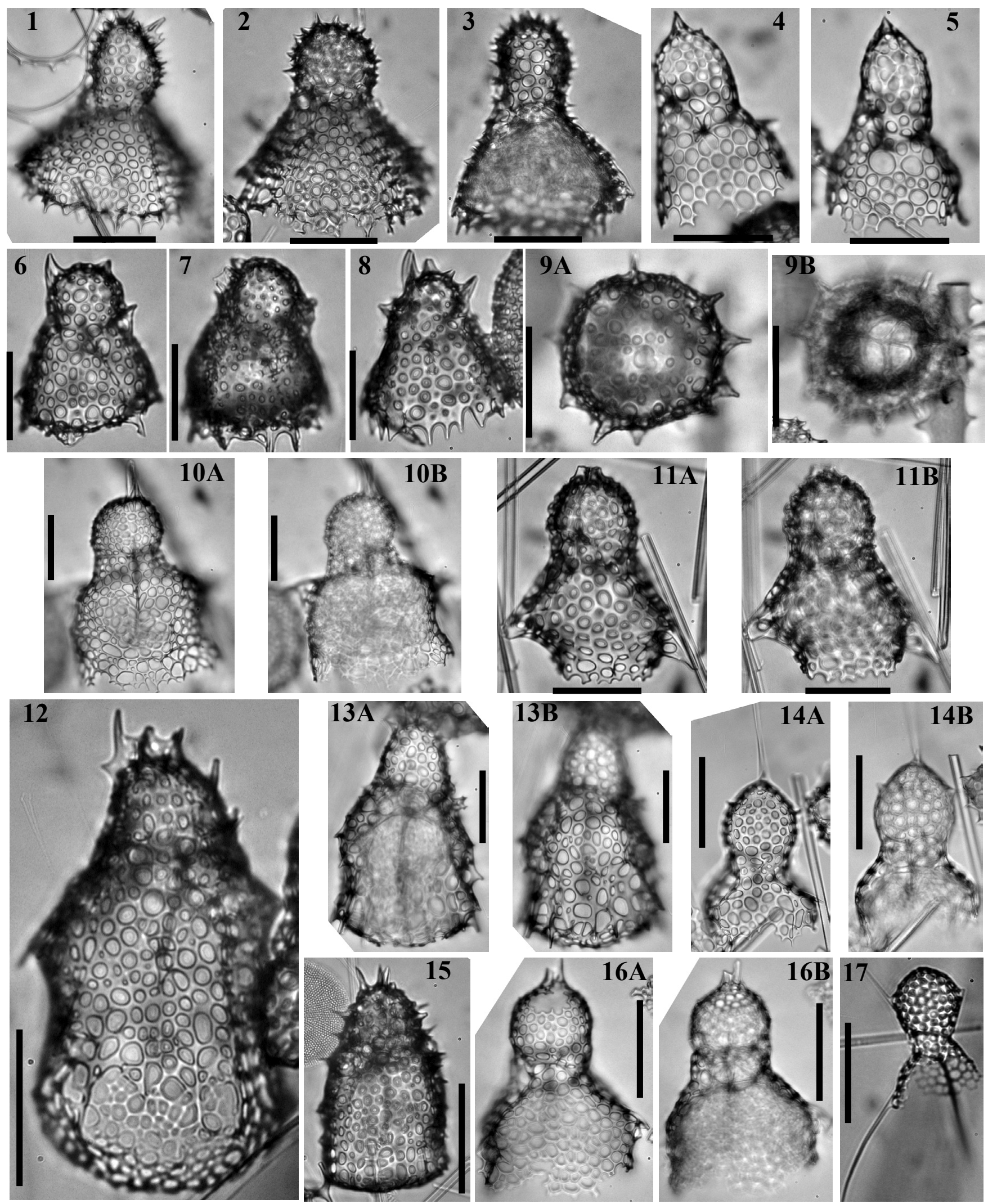
Lr project downwards, reach the thorax wall at its midst, continue on the wall as ribs until they become, at the thorax termination, blade-like feet. Cephalis is globular. Cephalis and thorax are distinctly separated by an inflated distally extended annular structure, delimited on top by arches $\mathbf{A V}$ and on the bottom by a fold that follows MB, which somewhat resembles a scarf. Pores on the cephalis and on the collar structure are small and more or less circular while pores on the thoracic wall are larger and slightly more elliptical. They both seem to be arranged in a hexagonal pattern. Thorax termination is ragged.

Dimensions. (Based on 4 specimens.) Length of the eucephalic lobe: 26-35 (30); total length (excluding feet): 68-92 (81).

Occurrence. Rare from the Cycladophora golli regipileus Zone to the Actinomma golownini Zone (Early to Middle Miocene), then sporadic until the Chi Zone (Pleistocene). Based on specimens reported by Lazarus \& Pallant (1989) this species ranges into the Early Oligocene.

Remarks. This species differs from the Lophophaena macrencephala Clark \& Campbell, 1945 group as illustrated in Dzinoridze et al. (1976) and Lophophaena mugaica (Grigorjeva, 1975) as illustrated in Kozlova (1999, pl. 3, fig. 16; pl. 4, fig. 3) primarily in possessing three well-developed feet. L. mugaica seems to share the same collar structure while L. macrencephala does not. Lophophaena clevei Petrushevskaya, 1971 (see P1. 7, fig. 17 herein) also shares this structure (though slightly reduced in volume) and possesses three feet as well; however, its size and the length ratio between its cephalis and its thorax are significantly different from that of the new species.

\section{Lophophaena pileata $\mathrm{n}$. sp.}

(P1. 7, figs 4-5)

Derivation of name. From the Latin pileatus (that wears a pointed hat).

Diagnosis. Hood-shaped cephalis with triangular apical horn unconnected to spine A.

Holotype. Plate 7, fig. 5; sample 120-747A-2H-5, 45-47 cm (Late Pliocene); ECO-062, circle 2.
Material. Eleven specimens observed in samples from ODP sites 737, 745, 747, 748 and 751.

Description. Dicyrtid with an ellipsoid cephalis elongated toward the apex where a short triangular, tribladed horn is present. This horn does not seem connected to any internal spine or apophyse. Indeed spine $\mathbf{A}$ is fused to the dorsal side of the cephalic wall and does not seem to protrude outside of it (though it is possible that it merges with the horn), nor do spines $\mathbf{V}$ (which joins the wall on the ventral side of the collar stricture) or D. Spines $\mathbf{L l}$ and $\mathbf{L r}$ are almost perpendicular to $\mathbf{M B}$ and join the wall in an intermediate position between the dorsal and the ventral side where, in some specimens (Pl. 7, fig. 4), they can protrude as very short wings. Thorax and cephalis are separated externally by furrows along arches $\mathbf{A L}$ and $\mathbf{V L}$ : because spines $\mathbf{L I}$ and $\mathbf{L r}$ are relatively close to spine $\mathbf{D}$, the furrow along $\mathbf{A L}$ forms a smaller angle with the one along VL thus forming a more-or-less marked dorsal shoulder. The thorax is more or less conical in outline. Pores on both segments are numerous, circular, of various sizes but generally relatively large (smaller toward the apex of the cephalis) and randomly arranged.

Dimensions. (Based on the 2 specimens illustrated.) Length of the cephalis: 60-62; total length: 106-108.

Occurrence. Sporadic from the Eucyrtidium punctatum Zone to the Chi Zone (Early Miocene to Pleistocene).

Remarks. The apical triangular horn unconnected to spine A seems characteristic of this species. This horn evokes that of Trisulcus boldyrae Petrushevskaya, 1971; however, the thorax outline of both those species differs completely from one another. Because the collar stricture follows arches $\mathbf{A L}$ and $\mathbf{V L}$ and because of the presence of a dorsal shoulder, the general outline of the cephalis is very similar to that of more common species, such as Lophophaena thaumasia Caulet, 1991 (which differs from L. pileata in its apical and ventral tribladed horn) and Lophophaena simplex Funakawa, 1994 (which differs from L. pileata in its numerous by-spines and its thorax ridges). This cephalis outline also evokes the kidney-shaped cephalis of species Lithomelissa celsagula and L. ehrenbergi discussed above; however, not only do those species lack a dorsal shoulder but they possess a more complex neck structure based on arches ap that $L$. simplex, L. thaumasia and L. pileata lack.

Explanation of Plate 7. fig. 1. Lophophaena? neuma n. sp. Sample 120-751A-12H-1, 98-102 cm. Holotype. fig. 2. Lophophaena? neuma n. sp. Sample 120-751A-12H-2, 98-102 cm. fig. 3. Lophophaena? neuma n. sp. Sample 120-751A-12H-2, 98-102 cm. fig. 4. Lophophaena pileata n. sp. Sample 120-747A-2H-5, 45-47 cm. fig. 5. Lophophaena pileata n. sp. Sample 120-747A-2H-5, 45-47 cm. Holotype. fig. 6. Botryopera piperata n. sp. Sample 120-748B-6H-3, 45-47 cm. fig. 7. Botryopera piperata $\mathrm{n}$. sp. Sample 120-748B-6H-7, 45-47 cm. Holotype. fig. 8. Botryopera piperata $\mathrm{n}$. sp. Sample 119-744A-10H-2, 60-62 cm. fig. 9. Botryopera piperata? Sample 120-751A-6H-1, 53-55 cm. Basal view: (A) focus on sieve plate; (B) focus on cephalic inner structure. fig. 10. Lithomelissa celsagula $\mathrm{n}$. sp. Sample 120-748B7H-4, 45-47 cm. Holotype, dorsal view: (A) focus on wing D; (B) focus on wings Ll and Lr. fig. 11. Lithomelissa celsagula n. sp. Sample 120-751A-3H-1, 98-102 cm: (A) focus on shell wall; (B) focus on inner structure. fig. 12. Antarctissa kjelli $\mathrm{n}$. sp. Sample 120-747A-2H-5, 45-47 cm. Holotype. fig. 13. Antarctissa kjelli n. sp. Sample 120-747A-2H5, 45-47 cm: (A) focus on MB; (B) focus on shell wall. fig. 14. Lithomelissa celsagula $\mathrm{n}$. sp. Sample 183-1138A-17R-2, 105-107 cm: (A) focus on cephalic wall; (B) focus on internal structure. fig. 15. Antarctissa kjelli $\mathrm{n}$. sp. Sample 120-747A-1H-1, 45-47 cm. Specimen with cylindrical thorax. fig. 16. Lithomelissa celsagula n. sp. Sample 120-748B-7H-4, 45-47 cm: (A) focus on cephalic wall; (B) focus on internal structure. fig. 17. Lophophaena clevei Petrushveskaya, 1971. Sample 119-744A-6H-1, 53-55 cm. All scale bars $50 \mu \mathrm{m}$. Magnification $\times 384$. 

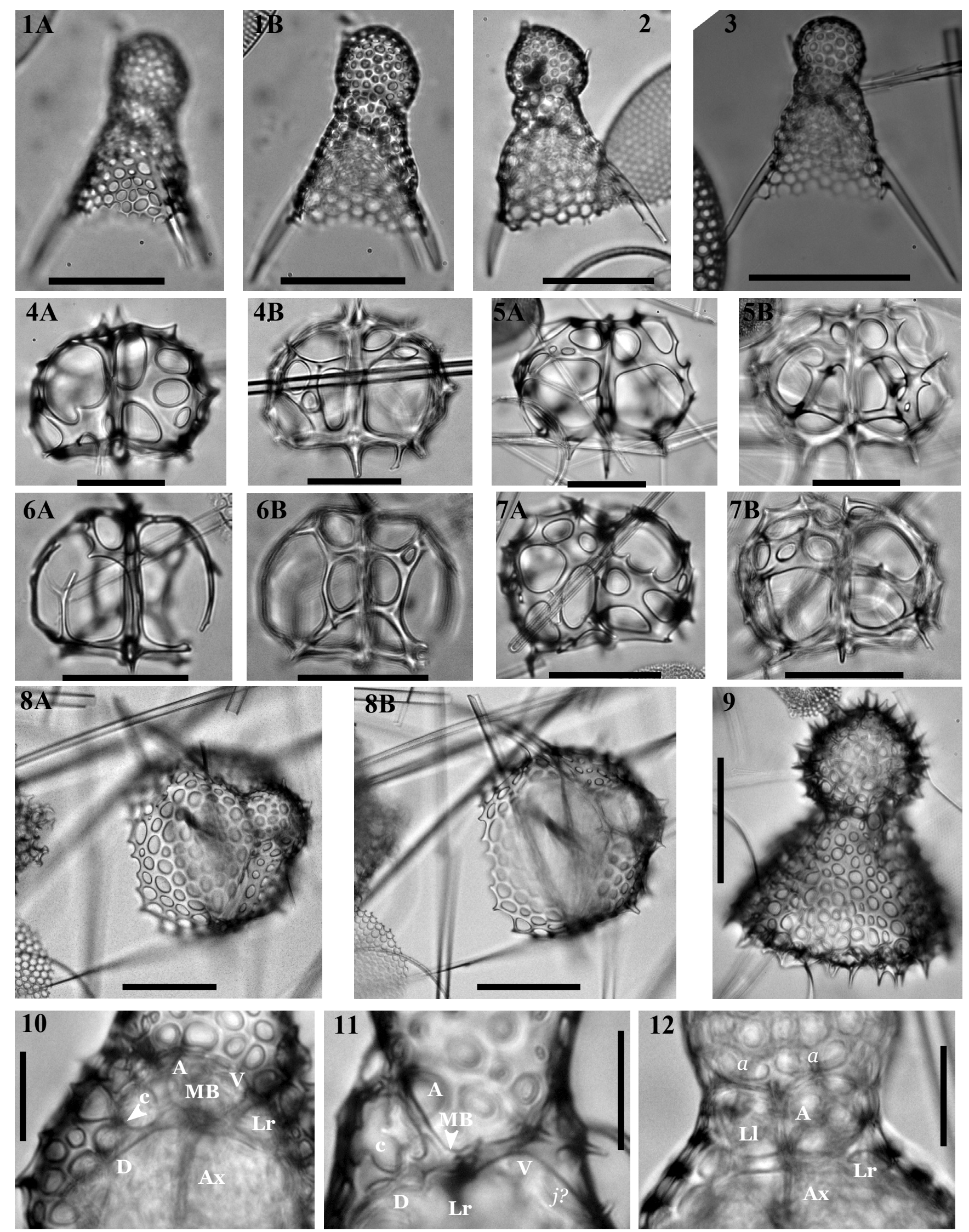
Lophophaena? globeacuculla $\mathrm{n}$. sp. (Pl. 4, figs 9A-B, 12)

Derivation of name. From the Latin globeus (spherical) and cuculla (cap).

Diagnosis. Characterized by its three blade-like feet, its large spherical cephalis and its three horns.

Holotype. Plate 4, fig. 9A-B; sample 120-748B-5H-7, 45-47 cm (Middle Miocene); ECO-045, circle 2.

Material. 119 specimens observed in samples from ODP sites 690, 693, 744, 747, 748, 751 and 1138.

Description. Large dicyrtid with a large, flattened, almost spherical cephalis and a truncated-conical to tetrahedral thorax. Both segments are separated by a clear collar stricture, above MB. Spine $\mathbf{A}$ is free in the cephalic cavity and protrudes subapically as a curved, conical horn. Two other supplementary horns that are very similar in shape and size to the apical horn are also present subapically on the cephalis. They do not seem to be connected with any internal spine or apophyse. Spine $\mathbf{V}$ reaches the wall at the cephalic stricture but does not seem to continue outside as a horn. Spines $\mathbf{D}, \mathbf{L I}$ and $\mathbf{L r}$ are projected downward, reach the thoracic wall at the third of its height and continue after the thorax termination as fairly long, blade-like, smooth feet. Pores on the cephalis are smaller than pores on the thorax. Both are round to elliptical. The pores on the thorax are more or less quincuncially arranged. Bars are crested on the cephalis.

Dimensions. (Based on 3 specimens.) Length of the cephalis: 3650 (44); total length: 84-114 (103); maximum breadth: 78-105 (95).

Occurrence. Rare from the Cycladophora humerus Zone to the Acrosphaera australis zone (Middle to Late Miocene), then sporadic until the Psi Zone (Pleistocene).

Remarks. This species differs from species of the genus Pseudodictyophimus and from Theoperidae in the size and shape of its cephalis and the disposition of its collar stricture: in Theoperidae, the collar stricture is systematically situated at the same height as MB, while in Pseudodictyophimus the separation between the two external segments follows furrows along arches AL and VL (Funakawa, 1995a) which is clearly not the case here. It is distinguished from Lophophaena witjazii (Petrushevskaya, 1971) in its apical horns being cylindrical instead of tribladed, its large thorax and in its three feet and from L. capito Ehrenberg, 1874 in its large thorax and in lacking wings.

Lophophaena? neuma n. sp.
(P1. 7, figs $1-3$; Pl. 8, fig. 9)

Derivation of name. From the Latin neuma (ghost), for the resemblance of the species with the depiction of ghosts in modern popular culture.

Diagnosis. Flaring thorax with teeth at the rim; elongated cephalis; whole shell covered with thorns.

Holotype. Plate 7, fig. 1; sample 120-751A-12H-1, 98-102 cm (Middle Miocene); ECO-078.

Material. 44 specimens observed in samples from ODP sites 748 and 751 .

Description. Dicyrtid with a spherical to apically elongated cephalis and a largely flaring truncated-conical thorax. Thorax ends on a circular rim where numerous small triangular teeth project. Spine $\mathbf{A}$ is fused to the dorsal side of the cephalic wall and can protrude outside the wall as a short triangular spine that can be hardly differentiated from the multitude of conical thorns projecting from the bar nodes of the cephalic wall and the upper thoracic wall. Spines $\mathbf{D}, \mathbf{L l}$ and $\mathbf{L r}$ join the upper thoracic wall and continue as ribs. Some specimens (Pl. 7, fig. 1) exhibit a more-orless marked pore alignment following these ribs. Pores on the thorax are more or less even in size, circular to elliptical and numerous. Pores on the cephalis are slightly smaller than those on the thorax in general. The cephalic wall can be rough and crested in some specimens (P1. 7, fig. 1).

Dimensions. (Based on 6 specimens.) Length of the cephalis: 44 58 (54); total length: 113-132 (127); maximum breadth: 80-114 (110).

Occurrence. Found sporadically from the Cycladophora golli regipileus Zone to the Acrosphaera australis Zone (Early to Late Miocene), rare in the Actinomma golownini Zone (Middle Miocene).

Remarks. This species differs from Lophophaena nadezdae Petrushevskaya, 1971 and L. simplex Funakawa, 1994 in its flaring thorax, in its whole shell being covered by tiny, needle-like thorns and its thorax terminating with a ring of small triangular teeth, slightly above the rim. It also differs from L. hispida

Explanation of Plate 8. fig. 1. Lophophaena amictoria n. sp. Sample 119-744A-2H-4, 53-55 cm: (A) focus on feet Lr; (B) focus on cephalic wall. fig. 2. Lophophaena amictoria $\mathrm{n}$. sp. Sample $119-746 \mathrm{~A}-7 \mathrm{H}-2,53-55 \mathrm{~cm}$. Holotype. fig. 3. Lophophaena amictoria n. sp. Sample 119-744A-4H-2, 59-61 cm. fig. 4. Ceratospyris clinamen n. sp. Sample 119-744A-6H-4, 60-62 cm. Holotype: (A) frontal view; (B) dorsal view. fig. 5. Ceratospyris clinamen n. sp. Sample 120-748A-5H-5, 45-47 cm: (A) dorsal view; (B) frontal view. fig. 6. Ceratospyris clinamen? Sample 120-748A-5H-4, 45-47 cm: (A) dorsal view; (B) frontal view. fig. 7. Ceratospyris clinamen n. sp. Sample 120-748A-5H-4, 45-47 cm: (A) frontal view; (B) dorsal view. fig. 8. Pseudodictyophimus ignatius n. sp. Sample 120-751A-10H-4, 98-102 cm. Specimen seen in apical view: (A) focus on cephalis wall; (B) focus on MB. fig. 9. Lophophaena? neuma $\mathrm{n}$. sp. Sample 120-751A-12H-2, 98-102 cm. Specimen with spherical cephalis. fig. 10. Antarctissa kjelli n. sp. Close-up of specimen from Plate 7, fig. 13A-B. fig. 11. Amphiplecta? satoshii n. sp. Enlargement of specimen (holotype) from Plate 5, fig. 11. fig. 12. Lithomelissa celsagula $\mathrm{n}$. sp. Enlargement of specimen from Plate 7, fig. 14A-B. Scale bars are $50 \mu \mathrm{m}$ for $1 \mathrm{~A}-9,10 \mu \mathrm{m}$ for $10-12$. Magnification $\times 384$ except for 8A-B ( $\times 192)$ and 6A-7B (×358.4). A: apical spine; D: dorsal spine; V: ventral spine; MB: median bar; Ax: axobate; Lr and LI: primary lateral spines; $a$ : anterior apophyse on spine $\mathbf{A} ; c$ : cervical apophyse on spine $\mathbf{D} ; j$ : jugal apophyses on spine $\mathbf{V}$. 
(Ehrenberg, 1872) in the cephalic pores and the cephalic thorns being considerably smaller and in the flaring thorax of L.? neuma. Although L.? neuma differs from Petrushevskaya's (1971) generic concept for Lophophaena, because of the numerous similarities with the three species mentioned here, this species is tentatively assigned to this genus.

Genus Pseudodictyophimus Petrushevskaya, 1971

Type species. Dictiophymus gracilipes Bailey, 1856.

Pseudodictyophimus ignatius $\mathrm{n}$. sp. (P1. 4, figs 10A-11B; Pl. 8, fig. 8A-B)

Derivation of name. After Ignatius J. Reilly, main character of John Kennedy Toole's A Confederacy of Dunces.

Diagnosis. Large species of Pseudodictyophimus with numerous thorns, a widely opening thorax.

Holotype. Plate 4, fig. 10A-B; sample 120-751A-13H-2, 98$102 \mathrm{~cm}$ (Middle Miocene); ECO-079.

Material. 394 specimens were observed in samples from ODP sites 689, 690, 693, 744, 746, 747, 748, 751 and 1138 .

Description. Large dicyrtid with a dome-shaped cephalis, bearing small rounded pores, an apical and ventral horns (usually tribladed at least at their base) and, often, numerous additional horns. The thorax is at least twice as wide and long as the cephalis. Both segments are separated by furrows along arches $\mathbf{A L}$ and $V \mathbf{L}$. Spines $\mathbf{D}, \mathbf{L I}$ and $\mathbf{L r}$ join the wall at the collar stricture, continue on at least half the length of the thorax, in the thoracic wall as ribs and then protrude as fairly long, downward-directed, conical to blade-like wings. Pores on the thorax are round to elliptical, relatively large (somewhat larger next to the ribs). Additional spines on the upper part of the thorax are frequent.

Dimensions. (Based on 4 specimens.) Total length: 89-104 (95); maximum breadth: 107-113 (109).

Occurrence. Sporadic from the Cycladophora antiqua Zone to the Cycladophora golli regipileus Zone (Early Miocene), then rare until the Upsilon Zone (Late Pliocene).

Remarks. It differs from $P$. tanythorax Funakawa, 1994 and $P$. gracilipes Bailey, 1856 in the flaring of its thorax, its size and the presence of additional horns. It differs from $P$. platycephalus (Haeckel, 1887) primarily in the latter having a collar stricture barely marked externally and from the specimen illustrated as Dictyophimus cf. platycephalus in Abelmann (1990) in its size and the width ratio of its cephalis and thorax; from Tripophaenoscenium laimingi Campbell \& Clark, 1944 in its shorter apical horn, the thinner wall, the smaller pores and, more noticeably, in its size (the total length of $T$. laimingi being often more than $400 \mu \mathrm{m}$ and its width more than $200 \mu \mathrm{m}$; as per Campbell \& Clark (1944) and personal observations on the specimens observed in the Southern Ocean); from Clathromitra pterophormis Haeckel, 1887 in the same characters as above, and additionally in lacking a large dendritic Ax; from Spongomelissa dilli Chen, 1975 and Corythomelissa omoprominentia Funakawa, $1995 a$ in possessing long wings/feet but lacking a rimmed peristome; from Corythomelissa horrida Petrushevskaya, 1975 and from C. spinosa Funakawa, 1995a in being larger, in having a wider, open thorax and in the collar stricture being distinct externally; from Corythomelissa pachyostraca Funakawa, 1995a, primarily in its weaker and shorter appendages but also in its additional spines.

Genus Spongomelissa Haeckel, 1887

Type species. Lithomelissa spongiosa Bütschli, 1882.

Spongomelissa? bipatens $\mathrm{n}$. sp.

(P1. 6, figs 1A-3B)

Derivation of name. From the Latin word 'bipatens' meaning 'with two openings'; after the two apical openings that seem typical of this species.

Diagnosis. Large bell-shaped skeleton; cephalis, in apical view, separated into three by apophyses $g$.

Holotype. Plate 6, fig. 1A-C; sample 120-748B-8H-2, 45-47 cm (Early Miocene); ECO-080, circle 1.

Material. 11 specimens observed in samples from ODP site 748.

Description. Large dicyrtid with a large bell-shaped thorax that ends on a short poreless rim with several short triangular teeth. No visible constriction or change in contour at the collar stricture. Spine $\mathbf{A}$ is free in the cephalic cavity and protrudes apically as a short tribladed horn. The cephalic wall, in apical view, is separated in three sectors: one is latticed, with round to elliptical pores and thick bar nodes with thorns and the two others are one large pore each (may be covered by a velum; Pl. 6, fig. 1A) delimited by a strong, thick circular arch extending from apophyses $g$. MB is reduced. Apophyses $a$ can be seen joining A with the shell wall (P1. 6, fig. 3B). Still in apical view, the thorax contour is irregular with a few triangular spines extending laterally from the largest part of the bell-shaped thorax: some of them could be wings extending from $\mathbf{D}, \mathbf{L} \mathbf{l}$ and $\mathbf{L l}$, or even unobserved l'. Pores on the thorax are numerous, large, regularly arranged and spaced, and elliptical. Spines D, V, Ll and $\mathbf{L r}$ seem to be all in the same horizontal plane (Pl. 6, fig. 1B) and do not seem to extend as horns or feet, but possibly wings (yet unconfirmed). No $\mathbf{A x}$ has been observed.

Dimensions. (Based on 4 specimens.) Maximum breadth of thorax: 159-202 (188).

Occurrence. Sporadic from the Stylosphaera radiosa to the Eucyrtidium punctatum Zone (Late Oligocene to Early Miocene).

Remarks. The peculiar cephalic structure of this species sets it aside from the other lophophaenids or clathromitrids present in the Southern Ocean, rendering the generic assignment problematic. This structure evokes that of the specimens illustrated by Sanfilippo \& Riedel (1973) as Velicucullus sp. (Sanfilippo \& Riedel, 1973, pl. 20, figs 5-6; pl. 34, fig. 14) but the rest of the 
skeleton differs widely from our new species (specifically the shell flattening and the thorax termination). It differs from Spongomelissa adunca Sanfilippo \& Riedel, 1973 and S. euparyphus Sanfilippo \& Riedel, 1973 in lacking feet, in the shell flattening of these two species and in the cephalis being reduced in height; from Spongomelissa dilli Chen, 1975 and Corythomelissa omoprominentia Funakawa, 1995a in the presence of teeth at the rim, in being taller and in its peculiar cephalic structure; from Corythomelissa horrida Petrushevskaya, 1975, C. pachyostraca Funakawa, 1995a and C. spinosa Funakawa, 1995a in lacking feet, in possessing a rim at the thorax termination and in its shorter apical horn.

Family Trissocyclidae Haeckel, 1881 emend. Goll, 1968 Genus Ceratospyris Ehrenberg, 1847 sensu Nigrini, 1967

Type species. Haliomma? radicatum Ehrenberg, 1844.

$$
\text { Ceratospyris clinamen n. sp. }
$$$$
\text { (P1. 8, figs 4A-7B) }
$$

Derivation of name. Latin term meaning 'deviation': term coined by Lucretius to express Epicurus' idea of the unpredictability of the physical world; used here for the apparent randomness of this species' bar disposition.

Diagnosis. Wide bilobed cephalis, loose latticed shell joining asymmetrically the sagittal ring.

Holotype. Plate 8, fig. 4A-B; sample 119-744A-6H-4, 60-62 cm (Middle Miocene); ECO-081.

Material. 972 specimens observed in ODP sites 744, 747, 748, 751 and 1138 .

Description. Bilobed cephalis with a weak sagittal constriction and a loose latticed shell wall that appears to be asymmetrical on both sides of the sagittal ring. Elliptical pores are randomly distributed and of various sizes. Bars are generally wide and often crested. The lattice wall joins the sagittal ring at the apex, in the middle of its frontal side and in the upper two-thirds of the dorsal side. The shell is wider than its height.

Spine $\mathbf{A}$ and spine $\mathbf{D}$ both extend as fairly significant spines, one near the apex of the sagittal ring, the other near the antapex. Some additional spines, more modest in size, can be seen arising from some bar nodes. Spine $\mathbf{V}$ seems to be visible on the frontal side (see the knob-like thickening of the sagittal ring near its base (Pl. 8, figs 4A and 5A).

Dimensions. (Based on 5 specimens.) Height of the sagittal ring: 58-76 (70); width of the shell: 91-113 (102).

Occurrence. Common in the Cycladophora spongothorax Zone (Middle to Late Miocene), sporadic until the Siphonosphaera vesuvius Zone (Late Miocene).

Remarks. This species differs from Eucoronis fridtjofnanseni Goll \& Bjørklund, 1980, from Ceratospyris borealis Bailey, 1856 and from Lophospyris cheni Goll, 1976 primarily in its considerably wider cephalic lobes. Additionally it differs from $E$. fridtjofnanseni and $C$. borealis in its deeper sagittal constriction and in the lattice wall connecting also to the middle of the sagittal ring and not exclusively to the top and bottom of it; and from $L$. cheni in its lattice wall bars being wider and flatter. It also shares, to some extent, similarities with Clathrospyris sandellae Goll, 1978 but they can be distinguished in the latter lacking an apical spine, having feet and in the latticed wall joining those feet distally. It is finally distinguished from other species of the genus Ceratospyris, such as C. laventaensis Campbell \& Clark, 1944, which are also found in the middle Miocene Southern Ocean, in its peculiar asymmetrical lattice wall.

Genus Dorcadospyris Haeckel, 1881 emend. Goll, 1969

Type species. Dorcadospyris dentata Haeckel, 1887.

Dorcadospyris? kennetti n. sp.

(Pl. 4, figs 4-5B)

Derivation of name. Named after James Kennett, for his contribution to Southern Ocean palaeoceanography.

Diagnosis. Thorny trissocyclid with randomly distributed pores, no sagittal constriction and no sagittal-lattice pores on the dorsal side.

Holotype. Plate 4, fig. 4; sample 120-748B-8H-2, $45-47 \mathrm{~cm}$ (Early Miocene); ECO-080, circle 2.

Material. 153 specimens observed in samples from ODP sites 689, 748, 751 and 1138 .

Description. Hemispherical to spherical cephalis separated into two chambers by a sagittal ring. No sagittal constriction. Ventral side of the cephalis shows several unpaired sagittal-lattice pores but dorsal side does not have any sagittal-lattice pores. The other pores on the shell wall are large, round to elliptical and more-or-less regularly arranged. Spine A extends as a short, conical apical horn. Spines D, Ll and Lr continue as fairly long, thin, conical feet that are bent downwards. Numerous thorns arise from bar nodes as thin, needlelike supplementary horns slightly shorter than the apical horn.

Dimensions. (Based on 3 specimens.) Height of the sagittal ring: 42-48 (46); maximum breadth: 48-59 (54).

Occurrence. Rare, from the Stylosphaera radiosa Zone to in the Cycladophora spongothorax Zone (Late Oligocene to Late Miocene). Found sporadically until the Siphonosphaera vesuvius Zone (Late Miocene).

Remarks. This species differs from the two Oligocene morphotypes illustrated as Do2 and Do4 in Goll (1969, text-fig. 2) in being covered by needle-like thorns and in having fewer, larger pores. It differs from Ceratospyris echinus Ehrenberg, 1874 (see Ogane et al., 2009, pl. 9, fig. 5a-d) and from C. setigera Ehrenberg, 1874 (see Ogane et al., 2009, pl. 9, fig. 3a-c) primarily in having fewer, larger pores but also in its fewer, longer feet and shorter spines; from C. heptaceros Ehrenberg, 1874 (see Ogane et al., 2009, pl. 38, fig. 7a-c) and Giraffospyris didiceros 
(Ehrenberg, 1874) in having larger, randomly distributed pores and more numerous, shorter spines.

\section{CONCLUSIONS}

Some of the new species presented in this paper may provide useful biostratigraphic information because of their abundance and continuity in the studied material or their short, well-defined range: Arachnocorallium? pyroensis, A. cerebellum, Hexacontium? cooki, Phormostichoartus ashbyi, Ceratospyris clinamen and Spongoplegma dentifrangibula. Some species, such as Arachnocorallium cerebellum (which peaks at $7 \%$ of some assemblages), Arachnocorallium? pyroensis and Ceratospyris clinamen (both up to 6\%), Spongoplegma dentifrangibula (up to 3\%), Hexacontium? cooki and Phormostichoartus ashbyi (both up to $2 \%$ ) or Arachnocorallium stilla (up to $1 \%$ of some samples) are abundant enough not to be overlooked in ecological or macroevolutionary studies. But, most importantly in this paper, many Plagiacanthidae (and most specifically many Lophophaenidae sensu Petrushevskaya (1971)) are described: Botryopera piperata, B. vavato, Antarctissa kjelli, Amphiplecta? satoshii, Arachnocorallium? pyroensis, A. cerebellum, A. stilla, Lophophaena? neuma, L. pileata, L.? cuculla, L. amictoria, Lithomelissa celsagula, Pseudodictyophimus ignatius, Ceratocyrtis? arthuri, C.? ringisstola and Spongomelissa? bipatens. This complex group is very diversified and abundant in the Neogene Southern Ocean. All these new species, along with the ones described in our previous papers (Renaudie \& Lazarus 2012, 2013) will be essential to understanding this group's evolution.

\section{ACKNOWLEDGEMENTS}

The authors would like to thank Kjell R. Bjørklund and F. John Gregory for their constructive, thorough reviews; and IODP for providing samples. This work was done in the context of a project supported by DFG (German Science Foundation) grant LA1191/8-1 and -2 .

\section{Manuscript received 12 December 2013 \\ Manuscript accepted 31 October 2014}

Scientific editing by F. John Gregory.

\section{REFERENCES}

Abelmann, A. 1990. Oligocene to middle Miocene radiolarian stratigraphy of southern high latitudes from Leg 113, Sites 689-690, Maud Rise. In Barker, P.F. et al. (Eds), Proceedings of the Ocean Drilling Program, Scientific Results, 113. Ocean Drilling Program, College Station, TX, 675-708.

Abelmann, A. 1992. Early to Middle Miocene radiolarian stratigraphy of the Kerguelen Plateau, Leg 120. In Wise, S.W. Jr. et al. (Eds), Proceedings of the Ocean Drilling Program, Scientific Results, 120. Ocean Drilling Program), College Station, TX, 757-783.

Abramoff, M.D., Magelhaes, P.J. \& Ram, S.J. 2004. Image Processing with ImageJ. Biophotonics International, 11: 36-42.

Aita, Y., Suzuki, N., Ogane, K., Sakai, T., Lazarus, D., Young, J. \& Tanimura, Y. 2009. Haeckel Radiolaria Collection and the H.M.S. Challenger Plankton Collection. In Tanimura, Y. \& Aita, Y. (Eds), Joint Haeckel and Ehrenberg Project: Reexamination of the Haeckel and Ehrenberg Microfossil Collection as a historical and scientific legacy. Japan National Museum of Nature and Science, Monograph, Tokyo, 40: 35-45.

Alvira Martin, M.P. 1971. Los Radiolarios fósiles en yacimientos de Moronitas españolas. Boletin de la Real Sociedad Española de Historia Natural, Seccion Geológica, 69: 215-230.
Bailey, J.W. 1856. Notice of microscopic forms found in the soundings of the Sea of Kamtschatka. American Journal of Science and Arts, 2nd Series, 22: 1-6.

Barron, J.A., Baldauf, J.G., Barrera, E. et al. 1991. Biochronologic and Magnetochronologic synthesis of Leg 119 sediments from the Kerguelen Plateau and Prydz Bay, Antarctica. In Barron, J. \& Larsen, B. (Eds), Proceedings of the Ocean Drilling Program, Scientific Results, 119. Ocean Drilling Program, College Station, TX, 813-847.

Berggren, W.A., Kent, D.V., Swisher, C.C. \& Aubry, M.-P. 1995. A revised Cenozoic geochronology and chronostratigraphy. In Berggren, W.A., Kent, D.V. \& Hardenbol, J. (Eds), Geochronology, time scales and global stratigraphic correlations: a unified temporal framework for a historical geology. SEPM Special Volume, 54: 129-212.

Bjørklund, K.R. 1976a. Radiolaria from the Norwegian Sea, Leg 38 of the Deep Sea Drilling Project. In Talwani, M. et al. (Eds), Initial Reports of the Deep Sea Drilling Project, 38. US Government Printing Office, Washington, 1101-1168.

Bjørklund, K.R. 1976b. Actinomma haysi, n. sp., its Holocene distribution and size variation in Atlantic Ocean sediments. Micropaleontology, 23: 114-126.

Bjørklund, K.R., Dumitrica, P., Dolven, J.K. \& Swanberg, N.R. 2007. Joergensenium rotatile n. gen., n. sp. (Entactinaria, Radiolaria): its distribution in west Norwegian fjords. Micropaleontology, 53: 457-468.

Bohaty, S.M., Wise, S.W., Jr., Duncan, R.A., Moore, C.L. \& Wallace, P.J. 2003. Neogene diatom biostratigraphy, tephra stratigraphy, and chronology of ODP Hole 1138A, Kerguelen Plateau. In Frey, F.A., Coffin, M.F., Wallace, P.J. \& Quilty, P.G. (Eds), Proceedings of the Ocean Drilling Program, Scientific Results, 183. Ocean Drilling Program, College Station, TX, 1-53.

Boltovskoy, D. 1998. Classification and distribution of South Atlantic recent Polycystine Radiolaria. Palaeontologica Electronica, 1, http:// palaeo-electronica.org/1998_2/boltovskoy/issue2.htm

Burridge, A.K. \& Bjørklund, K.R. 2014. Inter- and intraspecific morphological variation of three Hexacontium (Radiolaria) species in three southern Norwegian fjords: H. gigantheum, H. pachydermum and $H$. enthacantum. Marine Micropaleontology, 110: 72-82.

Bütschli, O. 1882. Beiträge zur Kenntnis der Radiolarienskelette, insbesondere der der Cyrtida. Zeitschrift für wissenschaftliche Zoologie, 36: 485-540.

Campbell, A.S. 1951. New genera and subgenera of Radiolaria. Journal of Paleontology, 25: 527-530.

Campbell, A.S. \& Clark, B.L. 1944. Miocene Radiolarian faunas from Southern California. Geological Society of America, Special Papers, 51: $76 \mathrm{pp}$.

Caulet, J.-P. 1986. A refined radiolarian biostratigraphy for the Pleistocene of the temperate Indian Ocean. Marine Micropaleontology, 11: 217-229.

Caulet, J.-P. 1991. Radiolarians from the Kerguelen Plateau, ODP Leg 119. In Barron, J. \& Larsen, B. (Eds), Proceedings of the Ocean Drilling Program, Scientific Results, 119. Ocean Drilling Program, College Station, TX, 513-546.

Cavalier-Smith, T. 2002. The phagotrophic origin of eukaryotes and phylogenetic classification of Protozoa. International Journal of Systematic and Evolutionary Microbiology, 52: 297-354.

Chen, P.H. 1975. Antarctic Radiolaria. In Hayes, D.E., Frakes, L.A. et al. (Eds), Initial Reports of the Deep Sea Drilling Project. US Government Printing Office, Washington, 28: 437-513.

Clark, B.L. \& Campbell, A.S. 1942. Eocene radiolarian faunas from the Mt. Diablo area, California. Geological Society of America, Special Papers, 39: 112pp.

Clark, B.L. \& Campbell, A.S. 1945. Radiolaria from the Kreyenhagen Formation near Los Banos, California. Geological Society of America, Memoirs, 10: 66pp.

De Wever, P., Sanfilippo, A., Riedel, W.R. \& Gruber, B. 1979. Triassic radiolarians from Greece, Sicily and Turkey. Micropaleontology, 25: 75-110. 
De Wever, P., Dumitrica, P., Caulet, J.-P., Nigrini, C. \& Caridroit, M. 2001. Radiolarians in the Sedimentary Record. Gordon and Breach, Amsterdam, 533pp.

Dogiel, V.A. \& Reshetnyak, V.V. 1952. Materialy po radiolyariyam severo-zapadnoy chasti tikhogo okeana. Issledovanya Dalnevostochnykh Morei SSSR, 3: 5-36.

Dumitrica, P. 1973. Cretaceous and Quaternary Radiolaria in deep sea sediments from the Northwest Atlantic Ocean and Mediterranean Sea. In Ryan, W. B. F. et al. (Eds), Initial Reports of the Deep Sea Drilling Project. US Government Printing Office, Washington, 13: 829-901.

Dumitrica, P. 1985. Internal morphology of the Saturnalidae (Radiolaria): systematic and phylogenetic consequences. Revue de Micropaléontologie, 28: 181-196.

Dumitrica, P. 1989. Internal skeletal structures of the Superfamily Pyloniacea (Radiolaria), a basis of a new systematics. Revista española de Micropaleontologia, 21: 207-264.

Dumitrica, P. 1991. Middle Triassic Tripedurnulidae, n. fam. (Radiolaria) from the eastern Carpathians (Romania) and Vicentinian Alps (Italy). Revue de Micropaléontologie, 34: 261-278.

Dzinoridze, R.N., Jousé, A.P., Koroleva-Golikova, G.S., Kozlova, G.E., Nagakeva, G.S., Petrushevskaya, M.G. \& Strelnikova, N.I. 1976. Diatom and Radiolarian Cenozoic Stratigraphy, Norwegian Basin; DSDP Leg 38. In Talwani, M. et al. (Eds), Initial Reports of the Deep Sea Drilling Project. US Government Printing Office, Washington, 38: 289-427.

Ehrenberg, C.G. 1839. Über die Bildung der Kreidefelsen und des Kreidemergels durch unsichtbare Organismen. Königlichen Preußischen Akademie der Wissenschaften zu Berlin, Abhandlungen, Jahre, 1838: 59-147.

Ehrenberg, C.G. 1844. Über 2 neue Lager von Gebirgsmassen aus Infusorien als Meeres-Absatz in Nord-Amerika und eine Vergleichung derselben mit den organischen Kreide-Gebirgen in Europa und Afrika. Monatsberichte der Königlich Preußischen Akademie der Wissenschaften zu Berlin, Jahre, 1844: 57-97.

Ehrenberg, C.G. 1847. Über die mikroskopischen kieselschaligen Polycystinen als mächtige Gebirgsmasse von Barbados und über das Verhältniss der aus mehr als 300 neuen Arten bestehenden ganz eigenthümlichen Formengruppe jener Felsmasse zu den jetzt lebenden Thieren und zur Kreidebildung. Königlichen Preußischen Akademie der Wissenschaften zu Berlin, Bericht, Jahre, 1847: 40-60.

Ehrenberg, C.G. 1854. Die systematische Charakteristik der neuen Mikroskopischen Organismen des Tiefen Atlantischen Oceans. Königlichen Preußischen Akademie der Wissenschaften zu Berlin, Bericht, Jahre, 1854: 236-250.

Ehrenberg, C.G. 1861. Über den Tiefgrund des stillen Oceans zwischen Californien und des Sandwich-Inseln. Königlichen Preußischen Akademie der Wissenschaften zu Berlin, Monatsbericht, Jahre, 1860: 819-833.

Ehrenberg, C.G. 1872. Mikrogeologische Studien über das kleinste Leben der Meeres-Tiefgründe aller Zonen und dessen geologischen Einfluss. Monatsberichte der Königlich Preußischen Akademie der Wissenschaften zu Berlin, 1871, 265-322.

Ehrenberg, C.G. 1874. Größere Felsproben des Polycystinen-Mergels von Barbados mit weiteren Erläuterungen. Monatsberichte der Königlich Preußischen Akademie der Wissenschaften zu Berlin, Jahre, 1873: 213262.

Ehrenberg, C.G. 1876. Fortsetzung der mikrogeologischen Studien als Gesammt übersicht der mikroskopischen Paläontologie gleichartig analysirter Gebirgsarten der Erde, mit specieller Rücksicht auf den Polycystinen-mergel von Barbados. Königlichen Preußischen Akademie der Wissenschaften zu Berlin, Abhandlungen, Jahre, 1875: 1-225.

Foreman, H.P. 1973. Radiolaria of Leg 10 with systematics and ranges for the families Amphipyndacidae, Artostrobiidae, and Theoperidae. In Worzel, J.L., Bryant, W. et al. Initial Reports of the Deep Sea Drilling Project, 10. US Government Printing Office, Washington: 407-474.
Funakawa, S. 1994. Plagiacanthidae (Radiolaria) from the Upper Miocene of Eastern Hokkaido, Japan. Transactions and Proceedings of the Palaeontological Society of Japan, New Series, 174: 458-483.

Funakawa, S. 1995a. Intrageneric variation and temporal change in the internal skeletal structure of plagiacanthids (Radiolaria) from Hokkaido, Japan. Transactions and Proceedings of the Palaeontological Society of Japan, New Series, 180: 208-225.

Funakawa, S. 1995b. Lophophaeninae (Radiolaria) from the upper Oligocene to lower Miocene and intrageneric variation in their internal skeletal structures. Journal of Geosciences, Osaka City University, 38: $13-59$.

Funakawa, S. 2000. Internal skeletal structures of the Cenozoic genera Gondwanaria, Lipmanella and Lithomelissa (Plagiacanthidae, Nassellaria) and their taxonomy. Micropaleontology, 46: 97-121.

Gersonde, R., Abelmann, A., Burckle, L.H. et al. 1990. Biostratigraphic synthesis of Neogene siliceous microfossils from the Antarctic Ocean, ODP Leg 113 (Weddell Sea). In Barker, P.F., Kennett, J.P. et al. (Eds), Proceedings of the Ocean Drilling Program, Scientific Results, 113. Ocean Drilling Program, College Station, TX: 915-936.

Goll, R.M. 1968. Classification and phylogeny of Cenozoic Trissocyclidae (Radiolaria) in the Pacific and Caribbean Basins, Part I. Journal of Paleontology, 42: 1409-1432.

Goll, R.M. 1969. Classification and phylogeny of Cenozoic Trissocyclidae (Radiolaria) in the Pacific and Caribbean Basins, Part II. Journal of Paleontology, 43: 322-339.

Goll, R.M. 1976. Morphological intergradation between modern populations of Lophospyris and Phormospyris (Trissocyclidae, Radiolaria). Micropaleontology, 22: 379-418.

Goll, R.M. 1978. Five trissocyclids Radiolaria from site 338. In Talwani, M. et al. (Eds), Initial Reports of the Deep Sea Drilling Project, sup. to vol. 38, 39, 40 and 41. US Government Printing Office, Washington, 177-191.

Goll, R.M. 1979. The Neogene evolution of Zygocircus, Neosemantis and Callimitra: their bearing on nassellarian classification. Micropaleontology, 25, 365-396.

Goll, R.M. \& Bjørklund, K.R. 1980. The evolution of Eucoronis fridtjofnanseni, n. sp. and its application to the Neogene biostratigraphy of the Norwegian-Greenland Sea. Micropaleontology, 26, 356-371.

Goll, R.M. \& Bjørklund, K.R. 1989. A new radiolarian biostratigraphy for the Neogene of the Norwegian Sea: oDP Leg 104. In Eldholm, O., Thiede, J., Taylor, E. et al. (Eds), Proceedings of the Ocean Drilling Project, Scientific Results, 104. Ocean Drilling Program, College Station, TX: 697-737.

Grigorjeva, A.I. 1975. Radiolarii verkhnego mela i paleogene vostochnogo sklona Urala i Zaural'ya. Trudy Instityta Geologii $i$ Geokhimii, Sverdlovsk, USSR, 119: 102-109.

Haeckel, E. 1860. Über neue, lebende Radiolarien des Mittelmeeres. Monatsberichte der Königlich Preußischen Akademie der Wissenschaften zu Berlin, Jahre, 1860: 794-817.

Haeckel, E. 1862. Die Radiolarien (Rhizopoda Radiaria). Eine monographie. Reimer, Berlin, xiv $+572 p p$.

Haeckel, E. 1881. Entwurf eines Radiolarien-Systems auf Grund von Studien der Challenger-Radiolarien. Jenaische Zeitschrift für Naturwissenschaft, 15: 418-472.

Haeckel, E. 1887. Report on the Radiolaria collected by H.M.S. Challenger during the years 1873-1876. Report on the Scientific Results of the voyage of H.M.S. Challenger during the years 1873-1876. Zoology, 18: $1-1803$.

Harting, P. 1863. Bijdrage tot de kennis der mikroskopische fauna en flora van de Banda-Zee. Verhandelung, Koninklijke Akademie van Wetenschappen, Amsterdam, 10: 1-34.

Harwood, D.M., Lazarus, D.B., Abelmann, A. et al. 1992. Neogene integrated magnetobiostratigraphy of the central Kerguelen Plateau, Leg 120. In Wise, S.W. Jr. et al. (Eds), Proceedings of the Ocean Drilling Program, Scientific Results, 120. Ocean Drilling Program, College Station, TX, 1031-1052. 
Hertwig, R. 1879. Der organismus der Radiolarien. G. Fischer, Jena, $149 \mathrm{pp}$.

Hollande, A. \& Enjumet, M. 1960. Cytologie, évolution et systématique des Sphaeroïdés (Radiolaires). Archives du Muséum National d'Histoire Naturelle, 7: 1-134.

Hollis, C.J. 2002. Biostratigraphy and paleoceanographic significance of Paleocene radiolarians from offshore New Zealand. Marine Micropaleontology, 46: 265-316.

Hull, D.M. 1996. Paleoceanography and biostratigraphy of Paleogene radiolarians from the Norwegian-Greenland Sea. In Thiede, J. et al. Proceedings of the Ocean Drilling Program, Scientific Results, 151. Ocean Drilling Program, College Station, TX, 125-152.

Jørgensen, E.H. 1900. Protophyten und Protozöen in Plankton aus der norwegischen Westküste. Bergens Museums Aarbog [1899], 6: 51-112.

Jørgensen, E.H. 1905. The Protist plankton and the diatoms in bottom samples. VII. Radiolaria. In Nordgaard, O.. (Ed.), Hydrographical and Biological investigations in Norwegian Fiords, Bergen Museum Skrifter, Ser. 1: 114-141.

Kamikuri, S. 2010. New late Neogene radiolarian species from the middle to high latitudes of the North Pacific. Revue de Micropaléontologie, 53: 85-106.

Kling, S.A. 1973. Radiolaria from the eastern North Pacific, Deep Sea Drilling Project, Leg 18. In Kulm, L.D. et al. (Eds), Initial Reports of the Deep Sea Drilling Project, 18. US Government Printing Office, Washington: 617-671.

Kozlova, G.E. 1999. Radiolarii paleogene boreal'noi oblasti Rossii. Practicheskoe rykovodstvo po microfayne Rossii, VNIGRI, 9: 1-320.

Lazarus, D.B. 1990. Middle Miocene to Recent radiolarians from the Weddell sea, Antarctica, ODP Leg 113. In Kennett, J.P. et al. (Eds), Proceedings of the Ocean Drilling Program, Scientific Results, 113. Ocean Drilling Program, College Station, TX, 709-727.

Lazarus, D.B. 1992. Antarctic Neogene radiolarians from the Kerguelen Plateau, Legs 119 and 120. In Wise, S.W. et al. (Eds), Proceedings of the Ocean Drilling Program, Scientific Results, 120. Ocean Drilling Program, College Station, TX, 785-809.

Lazarus, D.B. 2006. The Micropaleontological Reference Center Network. Scientific Drilling, 3: 46-49.

Lazarus, D.B. \& Pallant, A. 1989. Oligocene and Neogene radiolarians from the Labrador Sea, ODP Leg 105. In Srivastava, S.P. et al. (Eds), Proceedings of the Ocean Drilling Program, Scientific Results, 105. Ocean Drilling Program, College Station, TX, 349-380.

Lazarus, D., Faust, K. \& Popova-Goll, I. 2005. New species of prunoid radiolarians from the Antarctic Neogene. Journal of Micropalaeontology, 24: $97-121$.

Lees, J.M. 2010. GEOmap: Topographic and Geologic Mapping. R package version 1.5-4.

Moore, T.C. 1973. Method of randomly distributing grains for microscope examination. Journal of Sedimentary Petrology, 43: 904-906.

Motoyama, I. 1996. Late Neogene radiolarian biostratigraphy in the subarctic Northwest Pacific. Micropaleontology, 42: 221-262.

Müller, J. 1858. Über die Thalassicollen, Polycystinen und Acanthometren des Mittelmeeres. Königlichen Preußischen Akademie der Wissenschaften zu Berlin, Abhandlungen, Jahre, 1858: 1-62.

Nakaseko, K. 1955. Miocene radiolarian fossil assemblage from the southern Tojama Prefecture in Japan. Science Reports, College of General Education, Osaka University, 4: 65-127.

Nakaseko, K. 1972. On the Spongoplegma antarcticum Haeckel. Science Reports, College of General Education, Osaka University, 20: 51-57.

Nigrini, C. 1967. Radiolaria in pelagic sediments from the Indian and Atlantic Oceans. Bulletin of the Scripps Institution of Oceanography, University of California, San Diego, La Jolla, California, 11: 1-125.

Nigrini, C. 1968. Radiolaria from eastern tropical Pacific sediments. Micropaleontology, 14, 51-63.

Nigrini, C. 1977. Tropical Cenozoic Artostrobiidae (Radiolaria). Micropaleontology, 23: 241-269.
Nishimura, H. 1990. Taxonomic study on Cenozoic Nassellaria (Radiolaria). Science Report of the Institute of Geosciences, University of Tsukuba, section B, 11: 69-172.

Ogane, K., Suzuki, N., Aita, Y., Sakai, T. \& Lazarus, D. 2009. Ehrenberg's radiolarian collections from Barbados. In Tanimura, Y. \& Aita, Y. (Eds), Joint Haeckel and Ehrenberg Project: Reexamination of the Haeckel and Ehrenberg Microfossil Collection as a historical and scientific legacy. Japan National Museum of Nature and Science, Tokyo, Monograph, 40: 97-106.

Petrushevskaya, M.G. 1965. Osobennosti i konstruktsii skeleta radiolyarii Botryoidae (otr. Nassellaria). Trudy Zoologicheskogo Instituta, 35: 79-118.

Petrushevskaya, M.G. 1967. Radiolyarii otryadov Spumellaria i Nassellaria antarkticheskoi oblasti. Issledovaniya Fauny Morei, Resultaty Biologicheskikh Issledovanii Sovetskoi Antarkticheskoi Ekspeditsii 1955-1958, 4: 1-186.

Petrushevskaya, M.G. 1968. Gomologii v skeletakh radiolyarii Nassellaria. 1. Osnovnye dugi v semeistve Cyrtoidea. Zoologicheskii Zhurnal, 47: 1296-1310.

Petrushevskaya, M.G. 1971. Radiolyarii Nassellaria v planktone mirovogo okeana. Issledovaniya Fauny Morei, 9: 1-294.

Petrushevskaya, M.G. 1975. Cenozoic radiolarians of the Antarctic, Leg 29, Deep Sea Drilling Project. In Kennett, J.P., Houtz, R.E. et al. (Eds), Initial Reports of the Deep Sea Drilling Project, 29. US Government Printing Office, Washington, 541-676.

Petrushevskaya, M.G. \& Kozlova, G.E. 1972. Radiolaria: leg 14, Deep Sea Drilling Project. In Hayes, D.E. et al. (Eds), Initial Reports of the Deep Sea Drilling Project. US Government Printing Office, Washington, 14: 495-648.

Petrushevskaya, M.G. \& Kozlova, G.E. 1979. Opisanie rodov i vidov Radiolyarii. Issledovaniya Fauny Morei, 23: 86-157.

Popofsky, A. 1908. Die Radiolarien der Antarktis. Deutsche SüdpolarExpedition 1901-1903, 10: 183-305.

Popofsky, A. 1912. Die Sphaerellarien des Warmwassergebietes. Deutsche Südpolar-Expedition 1901-1903, 13: 73-159.

Popofsky, A. 1913. Die Nassellarien des Warmwassergebietes. Deutsche Südpolar-Expedition 1901-1903, 14: 217-416.

Renaudie, J. \& Lazarus, D.B. 2012. New species of Neogene radiolarians from the Southern Ocean. Journal of Micropalaeontology, 31: 29-52.

Renaudie, J. \& Lazarus, D.B. 2013. New species of Neogene radiolarians from the Southern Ocean - Part II. Journal of Micropalaeontology, 32: 59-86.

Riedel, W.R. 1967. Some new families of Radiolaria. Geological Society of London, Proceedings, 1640: 148-149.

Riedel, W.R. \& Campbell, A.S. 1952. A new Eocene radiolarian genus. Journal of Paleontology, 26: 667-669.

Rüst, D. 1888. Beiträge zur Kenntniss der fossilen Radiolarien aus Gesteinen der Kreide. Palaeontographica, 34: 181-213.

Sanfilippo, A. \& Riedel, W.R. 1973. Cenozoic Radiolaria (exclusive of Theoperids, Artostrobiids and Amphipyndacids) from the Gulf of Mexico, DSDP Leg 10. In Worzel, J.L. et al. (Eds), Initial Reports of the Deep Sea Drlling Project, 10. US Government Printing Office, Washington, 475-611.

Sanfilippo, A. \& Riedel, W.R. 1980. A revised generic and suprageneric classification of the Artiscins (Radiolaria). Journal of Paleontology, 54: 1008-1011.

Shilov, V.V. 1995. Miocene-Pliocene radiolarians from leg 145, North Pacific. In Rea, D.K. et al. (Eds), Proceedings of the Ocean Drilling Program, Scientific Results, 145. Ocean Drilling Program, College Station, TX, 93-116.

Spencer-Cervato, C. 1999. The Cenozoic deep-sea microfossil record: explorations of the DSDP/ODP sample set using the Neptune database. Palaeontologia electronica, 2: 1-270.

Suzuki, N. 2006. Ontogenetic growth and variation in the skeletal structure of two late Neogene Sphaeropyle species (Polycystine radiolarians). Journal of Paleontology, 80: 849-866. 
Suzuki, N. \& Aita, Y. 2011. Radiolaria: achievements and unresolved issues: taxonomy and cytology. Plankton \& Benthos Research, 6: 69-91.

Suzuki, N., Ogane, K., Aita, Y., Sakai, T. \& Lazarus, D. $2009 a$. Reexamination of Ehrenberg's Neogene Radiolarian collections and its impact on taxonomic stability. In Tanimura, Y. \& Aita, Y. (Eds), Joint Haeckel and Ehrenberg Project: Reexamination of the Haeckel and Ehrenberg Microfossil Collection as a historical and scientific legacy, Japan National Museum of Nature and Science, Tokyo, Monograph. 40: 87-96.

Suzuki, N., Ogane, K. \& Chiba, K. 2009b. Middle to Late Eocene polycystine radiolarians from the Site 1172, leg 189, southwest
Pacific. News of Osaka Micropaleontologists, Special Volume, 14: 239296.

Takahashi, K. \& Honjo, S. 1981. Vertical flux of Radiolaria: a taxonquantitative sediment trap study from the western tropical Atlantic. Micropaleontology, 27: 140-190.

Tan, Z. 1993. The spumellarian Radiolaria of the Xisha Islands. Studia marina sinica, 34: 181-226.

Weaver, F.M. 1983. Cenozoic radiolarians from the Southwest Atlantic, Falkland Plateau region, Deep Sea Drilling Project, Leg 71. In Ludwig, W.J., Krasheninnikov, V.A. et al. (Eds), Initial Reports of the Deep Sea Drilling Project, 71. US Government Printing Office, Washington, 667-686. 
The

Geological

Society

serving science $\mathcal{E}$ profession

\section{Beoomea}

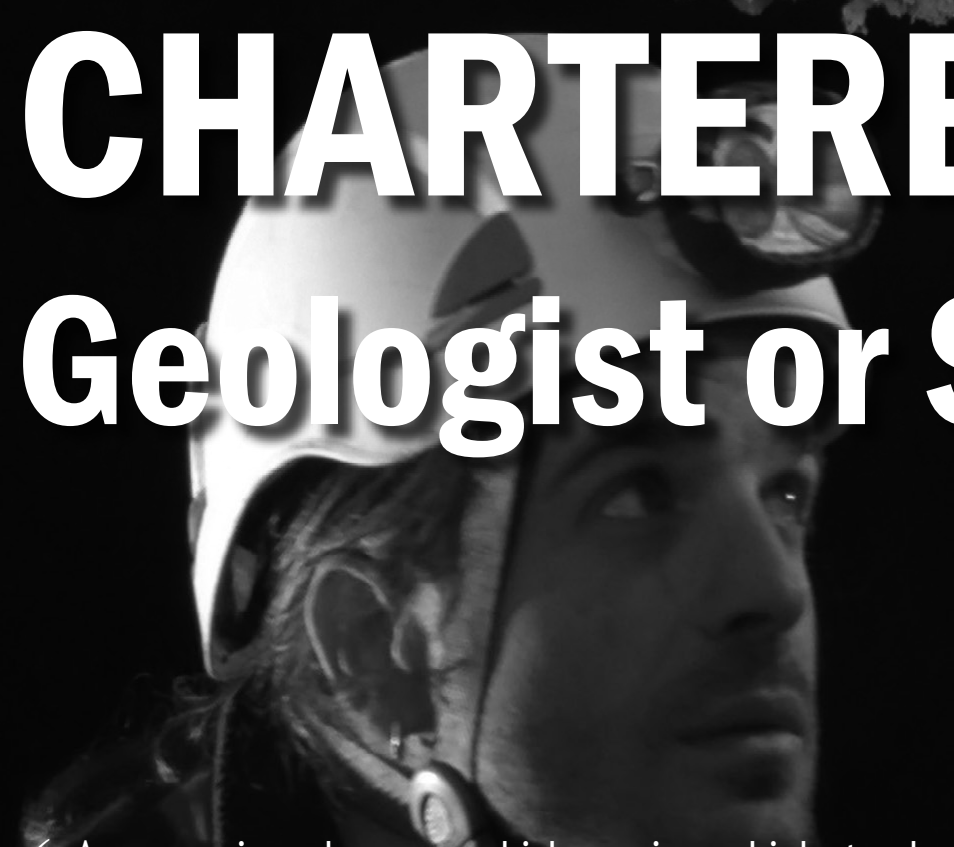

7. A peer reviewed process which requires a high standard of knowledge, competence and professionalism

$\checkmark$ The hallmark of professional achievement, recognised in the UK and in an expanding number of countries

$\checkmark$ Identifies you as competent and professional in your chosen speciality, and binds you to an enforced Code of Conduct $\checkmark$ Recognises your achievement within your industry and among your peers

$\checkmark$ In some sectors Chartered Geologists can sign off legal papers and reports

$\checkmark$ Chartered Geologist makes you eligible to apply for the title of European Geologist

\section{GGeol or CSci?}

\section{www.geolsoc.org.uk/chartership}

